\title{
Inequality and Equity in Bankruptcy Reorganization
}

\author{
Richard M. Hynes ${ }^{*} \&$ Steven D. Walt ${ }^{* *}$
}

\section{INTRODUCTION}

The maxim that in bankruptcy "equity is equality" routinely is invoked by courts and commentators. ${ }^{1}$ The goal of bankruptcy law, it is often said, is to treat creditors equally. In fact, the maxim is not reflected in the Bankruptcy Code. The Code recognizes numerous exceptions that allow deviations from equality of distribution from the estate. In their debtor's bankruptcy, creditors whose claims are secured by nonavoidable liens have priority over creditors with unsecured claims. ${ }^{2}$ Similarly, bankruptcy courts enforce contractual subordination agreements. ${ }^{3}$ The Code also gives certain unsecured claims, including tax claims, priority over other unsecured claims. ${ }^{4}$ In these instances, creditors are not treated equally. In light of the many exceptions to equality, the more accurate (but less succinct) maxim is the reverse of the "equality is equity" maxim: bankruptcy law respects inequalities created under nonbankruptcy law and the Bankruptcy Code, and requires equality in distribution only when these inequalities are not present. Inequality is equity in bankruptcy unless bankruptcy law requires equality.

Decisional law in bankruptcy reorganizations recognizes further exceptions to the "equity is equality" maxim. The critical vendor doctrine allows a vendor's prepetition debt to be paid as a condition of supplying

\footnotetext{
* John Allan Love Professor of Law, University of Virginia School of Law.

** Percy Brown Jr. Professor of Law \& Class of 1948 Professor of Scholarly Research in Law, University of Virginia School of Law. We thank participants at workshops at the Kansas University School of Law and the Canadian Law and Economics Association Annual Meeting for valuable comments, and Ian Carlin and Michael Gee for valuable research assistance. All errors remain our own.

1. See, e.g., Cunningham v. Brown, 265 U.S. 1, 13 (1924); see also EliZABETh WARREN, ET AL., The LAW of DeBtors AND CREDitors 58 (7th ed. 2014). For a recent article questioning the importance of this principle, see David A. Skeel, Jr., The Empty Idea of "Equality of Creditors," 166 U. PA. L. REV. 699 (2018).

2. 11 U.S.C. $\S \S 725,1129$ (b) (2012).

3. Id. $\S 510$.

4. Id. $\S 507$.
} 
new goods or services to a reorganizing debtor. ${ }^{5}$ Under prescribed conditions, the terms of post-petition credit can include payment or the securing of prepetition debt. ${ }^{6}$ And in limited circumstances the bankruptcy estates of different debtors can be consolidated with the result that distributions to unsecured creditors of one of the debtors are diminished. ${ }^{7}$ These judicially created exceptions to equality operate in different circumstances and have their own doctrinal requirements. However, they each allow certain creditors' claims to receive more favorable treatment than other claims with the same legal character, and they may allow these claims to receive more favorable treatment than claims that would otherwise be entitled to priority over them.

This paper concerns judicially approved deviations from equality in reorganizations. In these instances, courts effectively have concluded that inequality is equitable. Such deviations from equality raise at least two questions: how frequently do the deviations occur, and what is the implicit standard courts use in approving them? Although commentators have noted the incidence of the deviations from equality, their frequency remains anecdotal and relatively undocumented. We provide some new evidence to partially fill this gap.

Although the standards invoked by courts in approving deviations vary by context, we show that the deviations reveal a common pattern. A few courts flatly prohibit any deviation from bankruptcy's priority rules absent the consent of the disfavored parties. ${ }^{8}$ However, many other courts, including the United States Supreme Court, allow some deviations as long as the disfavored parties are also made better off or at least no worse off. ${ }^{9}$ These courts allow deviations only if they are Pareto improvements. ${ }^{10}$ Still, other courts allow deviations as long as the favored creditors gain more than the disfavored creditors; ${ }^{11}$ they approve a deviation as long as it is a Kaldor-Hicks improvement. ${ }^{12}$ Decisional law reflects a difference in the criteria that might be used to permit deviation from the Bankruptcy Code's priority rules and its norm of equality.

Part I describes bankruptcy priorities and judicially created exceptions to equality. Part II supplies evidence of the frequency with which courts

5. See infra Section I.A.

6. See infra Section I.B.E

7. See infra Section I.C. As explained below, one can conceive of substantive consolidation as a deviation from equality or as a form of inequitable equality. See infra Section I.B.3.

8. See infra note 100 and accompanying text.

9. See infra Section III.A.

10. Id.

11. Id.

12. Id. 
approve deviations from equality in critical vendor orders. Part III identifies the implicit standard courts tend to use in allowing deviations across a range of different exceptions to equality. It discusses the normative considerations in play in the choice among the three possible standards: an absolute prohibition allowing deviations, a Kaldor-Hicks standard, and a Pareto standard. This Part gives some reasons why most courts, in allowing deviations from equality, properly use a Pareto standard in preference to other possible standards.

\section{BANKRUPTCY'S STATUTORY AND NON-STATUTORY PRIORITIES}

\section{A. Bankruptcy's Standard Priority Rules}

In a Chapter 7 bankruptcy, the assets of the firm are sold and the proceeds are distributed to the creditors. The trustee must first dispose of any property subject to liens such as those held by secured creditors. ${ }^{13}$ Only if there is any money left over after satisfying these liens will other creditors receive anything. Next, the Bankruptcy Code grants priority to certain unsecured creditors. ${ }^{14}$ The list of priority claims is long, but a few deserve special attention. The Code grants priority to administrative expenses over general unsecured claims. ${ }^{15}$ These are usually claims incurred after the filing of the petition, but since 2005, the Code has granted administrative expense status to claims for goods received by the debtor within twenty days of the commencement of the case. ${ }^{16}$ The Bankruptcy Code also grants priority to a worker's claim for unpaid prepetition wages and employee benefits as long as they are below some dollar limit (currently \$12,850). ${ }^{17}$ Prepetition tax claims are a third important type of priority claim. ${ }^{18}$

After the priority claims are paid, any remaining proceeds are used to pay: i) first, unsecured claims that were timely filed, ii) second, unsecured claims that were filed late, iii) third, claims for fines, penalties, forfeitures or punitive damages, and iv) fourth, payment of interest on the above. ${ }^{19}$ If there are any remaining proceeds, they are given to the debtor. ${ }^{20}$ If the

\footnotetext{
13. 11 U.S.C. $\S 725(2012)$.

14. $\quad I d . \S \S 507,726$.

15. $I d$.

16. See id. §503(b)(9).

17. Id. $\S 507(\mathrm{a})(4),(5)$; Revision of Certain Dollar Amounts in the Bankruptcy Code, 81 Fed. Reg. 8748 (Feb. 22, 2016).

18. See 11 U.S.C. § 507(a)(8).

19. Id. $\S 726(\mathrm{a})$.

20. Id.
} 
proceeds are insufficient to pay any group in full, the members of the group share pro rata. ${ }^{21}$ Finally, the bankruptcy court can subordinate a claim, moving it lower in the priority waterfall, if the creditor agreed to this treatment prior to bankruptcy ${ }^{22}$ or if the court thinks that the creditor has engaged in inequitable conduct. ${ }^{23}$

Chapter 11 is designed to end in a plan of reorganization that determines the rights received by the various creditors. Claims are divided into classes based on their legal rights. Claims with different legal rights (e.g. a secured and an unsecured claim) cannot be placed in the same class, but claims with similar legal rights (e.g. an unsecured bank loan and unpaid trade bills) are sometimes placed in different classes. ${ }^{24}$ Claims placed in the same class are entitled to equal treatment, ${ }^{25}$ but the Code allows unequal treatment of claims in different classes. ${ }^{26}$ Indeed, unequal treatment is sometimes required. ${ }^{27}$ Secured creditors routinely receive much more than unsecured creditors ${ }^{28}$ because they can insist on a promise of future payments with a present value equal to the lesser of the value of their collateral or the amount that they are owed. ${ }^{29}$ Classes of unsecured creditors can insist on "absolute priority" that ensures that they will be paid in full or that claims junior to them receive nothing. ${ }^{30}$ For example, subordinated unsecured creditors cannot receive anything in a plan of reorganization unless more senior claims are either paid in full or consent to different treatment.

When two classes of claims enjoy equal priority, the Bankruptcy Code prohibits "unfair discrimination" between them. ${ }^{31}$ This language clearly

\footnotetext{
21. Id. $\S 726(\mathrm{~b})$.

22. Id. $\S 510(\mathrm{a})$.

23. Id. § 510(c); see, e.g., In re Kreisler, 546 F.3d 863, 865-66 (7th Cir. 2008); Benjamin v. Diamond (In re Mobile Steel Co.), 563 F.2d 692, 699-700 (5th Cir. 1977) (citations omitted).

24. See 11 U.S.C. $\$ 1122(2012)$.

25. See id. §1123(a)(4).

26. See, e.g., id. (negative implication of requirement that claims and interest in the same class receive the same treatment, unless they agree otherwise); id. $\S 1129$ (b) (nonconsensual plan confirmable only if it does not discriminate unfairly against class objecting to the plan); $\S$ 1129(b)(2)(B) (nonconsensual plan fair and equitable with respect to unsecured claims only if these claims are paid in full or junior claims or interests receive nothing).

27. See, e.g., id. § 507(a) (priority among unsecured claims); id. § 1129(b)(2)(B) (nonconsensual plan must pay unsecured claims in full or junior claims or interests receive nothing).

28. See, e.g., Arturo Bris, Ivo Welch \& Ning Zhu, The Costs of Bankruptcy: Chapter 7 Liquidation versus Chapter 11 Reorganization, 61 J. FIN. 1253 (2006) (finding that secured creditors received an average recovery of just over $90 \%$ while unsecured creditors received an average recovery of just over $50 \%$ ).

29. See 11 U.S.C. § 1129(b)(2)(A) (2012).

30. See id. § 1129(b)(2)(B).

31. See id. $\S 1129(\mathrm{~b})(1)$.
} 
contemplates some difference in treatment, and courts sometimes allow one class to be paid in a different manner than another or recover at a higher rate. ${ }^{32}$ The justification is obvious if one class enjoys priority for one of the reasons discussed above, and sometimes courts will allow a higher recovery for administrative convenience. ${ }^{33}$ For example, courts will sometimes allow small claims to be paid in full in cash. ${ }^{34}$ More controversial are instances where the court allows a creditor a greater recovery because the creditor is contributing to the reorganization of the firm or because the greater recovery is "necessary" for a reorganization. ${ }^{35}$ These justifications have much in common with the critical vendor doctrine discussed below, and we therefore postpone treatment of these doctrines. ${ }^{36}$

The Bankruptcy Code allows creditors to consent to less favorable treatment, and in Chapter 11 this consent is usually class based. That is, if a supermajority of the claims in a class approves the plan, the objecting creditors cannot raise an absolute priority or unfair discrimination objection. ${ }^{37}$ Individual creditors can object if they are not receiving at least as much as they would receive in a Chapter 7 liquidation, ${ }^{38}$ but this test is often not binding because the court thinks that a liquidation would yield very little value relative to the going concern value of the firm.

32. See, e.g., In re Kleigel Bros. Univeral Elec. Stage Lighting Co., 149 B.R. 306, 308-09 (Bankr. E.D.N.Y. 1992) (finding that a higher distribution on union members' wage claims did not unfairly discriminate in the face of a threat of strike when a union shop was needed for business to remain in industry); In re Perskin, 9 B.R. 626, 630-32 (Bankr. N.D. Tex. 1981) (finding that it was fair for plan to discriminate in favor of credit card debt when debtor needed access to cards to continue business); In re Ragsdale, 15 B.R. 668, 670-71 (Bankr. N.D. Ga. 1980) (finding fair discrimination in favor of creditor with a claim partly secured by a car needed for debtor's business); see also Richard M. Hynes \& Steven D. Walt, Fair and Unfair Discrimination in Municipal Bankruptcy, 37 CAMPBELL L. REV. 25, 34-43 (2015) (explaining the taxonomy of fair discrimination cases).

33. See, e.g., In re Cello Energy, LLC, Nos. 10-04877-MAM-11, 10-04931-MAM-11, 1004930-MAM-11, 2012 Bankr. LEXIS 1533, at *46-47 (Bankr. S.D. Ala. Apr. 10, 2012); In re Storberg, 94 B.R. 144, 146 (Bankr. D. Minn. 1988).

34. See In re Hanish, LLC, 570 B.R. 4, 17 (Bankr. D. N.H. 2017) (citations omitted) (relying on legislative history of 11 U.S.C. $\$ 1122$ (b) for the proposition that the provision allows payment in full of separately classified small claims); In re Storberg, 94 B.R. at 146 n.2 (assuming that 11 U.S.C. § 1122(b) separate classification of small claims allows for their special treatment); In re Jartran, 44 B.R. 331, 397 (Bankr. N.D. Ill. 1984) (finding that 11 U.S.C. § 1122(b) allows creation of a convenience class of small claims receiving immediate payment).

35. See Hynes \& Walt, supra note 32, at 28 (quoting Bruce A. Markell, A New Perspective on Unfair Discrimination in Chapter 11, 72 AM. BANKR. L.J. 227, 260 (1998)) ("“A] claim can fairly receive a higher return if the creditor holding the claim contributes to the reorginzation.").

36. See infra note 48 , and the accompanying text.

37. See 11 U.S.C. $§ 1129$ (b)(1) (2012) (requiring that a plan be fair and equitable with respect to and not discriminate against a class of claims that has not accepted the plan).

38. See id. $\S 1129(\mathrm{a})(7)$. 
As a final note, claims that enjoy priority status in Chapter 7 can demand special treatment in Chapter 11 as well. For example, holders of administrative expense claims can demand to be paid in full and in cash as a condition of confirmation of a plan of reorganization. ${ }^{39}$

\section{B. Non-Statutory Departures from Standard Priority Rules}

In this section we describe three common departures from bankruptcy's standard priority rules. Part 1 discusses critical vendor orders, or the payment of prepetition debts of certain vendors to ensure that they continue delivering to the debtor. Part 2 discusses roll-ups, or the prepetition payment of prepetition debts to induce a lender to provide post-petition financing. Part 3 discusses substantive consolidation, or ignoring the legal separateness of the corporations that comprise a firm.

\section{Critical Vendor Orders}

One of the first steps that many debtors take on filing for bankruptcy is to file motions for "first day orders." These include an order allowing them to pay their workers and suppliers for work performed and goods or services supplied prepetition. ${ }^{40}$ Debtors argue that they need to pay the workers or morale would suffer and some would quit. They also argue that they need to pay their "critical vendors" in full or these vendors cannot or will not continue delivering needed supplies.

The Supreme Court recently blessed these critical vendor orders in dicta in a case, Czyzewski v. Jevic Holding Corp. ${ }^{41}$ which dealt with a different issue. The United States Bankruptcy Court for the District of Delaware had ordered a structured dismissal that distributed funds to unsecured creditors ahead of workers whose claims would have enjoyed priority in either a Chapter 7 liquidation or a Chapter 11 reorganization. ${ }^{42}$ It reasoned that because the distributions did not occur in a plan of reorganization, the standard priority rules did not apply. ${ }^{43}$ The District

39. See id. $\$ 1129$ (a)(9)(A). Holders of wage claims can demand the same treatment if their class has rejected the plan. Id.

40. See Lynn P. Harrison \& James V. Drew, First Day Orders: A Survey of Critical Vendor Motions and Recent Developments, in PLI Course Handbook 1, 2-3 (2009); John D. Ayer, Michael Bernstein \& Jonathan Friedland, The Life Cycle of a Chapter 11 Debtor through the Debtor's Eye's: Part I, 22 AM. BANKR. INST. J. 20, 20 (2003).

41. 137 S. Ct. 973 (2017).

42. Id. at 978 .

43. Id. at 982 . 
Court of Delaware and the Third Circuit affirmed, ${ }^{44}$ but the Supreme Court reversed, holding that final distributions must comply with the standard priority rules unless the affected parties consent. ${ }^{45}$

In so doing, the Supreme Court contrasted final distributions, which must comply with the standard priority rules, with interim distributions such as wage and critical vendor orders and roll-ups. The Court noted that "courts [that have approved interim orders] have usually found that the distributions at issue would 'enable a successful reorganization and make even the disfavored creditors better off." 46 Other language from the Seventh Circuit case quoted by the Supreme Court, In re Kmart Corp. ${ }^{47}$ applies a slightly weaker standard, requiring only that the disfavored creditors be "as well off." 48 As explained more thoroughly in Part III, this is a Pareto standard. A reallocation is permissible if some are better off (the favored creditors) and none are worse off. ${ }^{49}$

The court in Kmart did not actually approve a critical vendor order. In fact, it thought that orders that would qualify would be extremely rare. In Kmart, the Seventh Circuit ruled that a critical vendor order could not be issued without proof that a disfavored creditor would be as well off with a reorganization as with a liquidation, and that the critical vendor would not have made deliveries if its old debt were not paid. ${ }^{50}$ It thought that the latter test is unlikely to be met because i) many suppliers must deliver pursuant to an executory contract, ii) prepetition debts are sunk costs and

\footnotetext{
44. Id.

45. Id. at 978 ("A distribution scheme ordered in connection with the dismissal of a Chapter 11 case cannot, without the consent of the affected parties, deviate from the basic priority rules that apply under the primary mechanisms the Code establishes for final distributions of estate value in business bankruptcies.").

46. Id. at 985 (citing In re Kmart Corp., 359 F.3d 866, 872 (7th Cir. 2004)).

47. 359 F.3d 866 (7th Cir. 2004).

48. Id. at 873. In applying a weaker standard, the Seventh Circuit drew an analogy to the unfair discrimination standard that applies both in Chapters 11 and 13. Id. at 874 .

49. Interestingly, the bankruptcy court thought that its structured dismissal order also passed a Pareto test because it thought the skipped creditors would receive nothing in the absence of the structured dismissal. "[T] he [bankruptcy] court predicted that without the settlement and dismissal, there was 'no realistic prospect' of a meaningful distribution for anyone other than the secured creditors." Jevic, $137 \mathrm{~S}$. Ct. at 982 . The funds to be distributed were to come from a settlement of a cause of action of the estate, and the defendant refused to settle unless the court agreed to the departure. Id. at 981-82. As a result, the bankruptcy court did not think that the priority creditors would be harmed by the deviation from the standard priority rules. Id. The Supreme Court did not think that this was enough, arguing that it did not leave the disadvantaged creditors better off. $I d$. at 986 . After the Court disapproved of the settlement, the debtor submitted a modified settlement plan which added $\$ 1$ million to pay priority claims. See In re Jevic Trucking Corp., Bankr. D. Del. February 22, 2018, 1:08-bk-11006 (motion). The modification suggests (without proving) that the original settlement did not pass the Pareto test.
}

50. Kmart, 359 F.3d at 872. 
should be ignored by rational actors, and iii) debtors can use devices such as letters of credit to secure future performance. ${ }^{51}$ Other courts have added an additional requirement: that the debtor show that the vendor is indeed critical. ${ }^{52}$ A vendor is critical when the debtor cannot get the goods or services from another supplier.

\section{Cross-Collateralization and Roll-Ups}

The debtor-in-possession often will want liquidity during a Chapter 11 reorganization. Creditors holding prepetition debt might be willing to make a postpetition loan on condition that both the loan and the prepetition debt is secured. The collateral (which might consist of assets acquired by the debtor pre- or postpetition) secures not only the postpetition loans but also debt the debtor incurred prior to its bankruptcy. This form of crosscollateralization enables the lender to fully secure unsecured or undersecured prepetition debt it holds. Under an alternative arrangement, a creditor holding undersecured or oversecured debt might condition its postpetition loan on the debtor using the loan proceeds to repay the prepetition debt. In this way the prepetition debt is converted or "rolled up" into postpetition debt, which is secured or entitled to administrative expense priority (or both). ${ }^{53}$ A variant is a gradual or "creeping" roll-up. Here, prepetition debt is not repaid with the proceeds of the postpetition loan. Instead, the debtor-in-possession ("DIP") loan agreement provides that repayments of cash collateral are credited to prepetition debt while sums advanced are deemed postpetition loans. ${ }^{54}$ Under the agreement the advances are to be made as, and in the amount of, the repayments the debtor receives from its account debtors. The amount of postpetition debt increases as the prepetition debt is repaid. As postpetition loans, the advances are entitled to administrative expense priority or are secured (or both).

Cross-collateralization and roll-ups, if authorized, both allow for deviations from Bankruptcy Code priority rules if the prepetition debt was not fully protected by an unavoidable security interest. Prepetition

\footnotetext{
51. Id. at $872-73$.

52. See, e.g., In re Zenus is Jewelry, 378 B.R. 432, 433-34 (Bankr. D. N.H. 2007); In re Tropical Sportswear Int'l Corp., 320 B.R. 15, 17 (Bankr. M.D. Fla. 2005); In re Just for Feet, 242 B.R. 821, 825-26 (Bankr. D. Del. 1999).

53. For a discussion of roll-ups, see Frederick Tung, Do Economic Conditions Drive DIP Lending? Evidence from the Financial Crisis (Bost. Univ. Sch. of Law, Law \& Econ. Res. Paper No. 16-38, Sept. 20, 2017), https://papers.ssrn.com/sol3/papers.cfm?abstract_id=2828295.

54. See Paul H. Zumbro, DIP and Exit Financing Trends and Strategies in a Changing Marketplace, in RECENT TRENDS IN DeBTOR IN POSSESSION FINANCING 3, 12 (2016), https://www.cravath.com/files/uploads/Documents/Publications/3616890_1.PDF.
} 
unsecured claims that are cross-collateralized are secured, thereby giving them priority over other prepetition unsecured claims. Like a critical vendor payment, a roll-up allows the debtor to repay prepetition unsecured debt. In this respect a roll-up is like a critical vendor payment. The critical vendor payment allows the repayment of prepetition unsecured or undersecured debt as a condition of obtaining postpetition goods or services. A roll-up allows repayment of the debt as a condition of obtaining postpetition financing. Like a critical vendor payment, a roll-up effectively enables the preferred creditor's claims to be treated more favorably than claims with the same legal character. When authorized, cross-collateralization and roll-ups deviate from equality defined by the Code's priority rules.

Whether the Bankruptcy Code gives courts the authority to allow cross-collateralization and roll-ups is controversial. Although the local rules of courts with active Chapter 11 dockets allow their use, with judicial oversight ${ }^{55}$ their statutory basis is unclear. No provision in the Code expressly authorizes these terms as part of DIP financing agreements. At the same time, none expressly prohibits the terms either. If the Code authorizes them, the likely statutory basis is in $\S 363$ or $\S 364$. Some courts have found that $\S 364$ does not authorize cross-collateralization. ${ }^{56}$ They therefore have inferred that the section prohibits the term. The inference is unsound because $\S 364$ says nothing about the permissible terms of a postpetition financing agreement. The section merely authorizes the DIP to obtain postpetition credit and describes the circumstances under which it can be obtained permissibly. An inference from $\S 363(\mathrm{~b})$ might give statutory authority for cross-collateralization and roll-ups. After all, the provision authorizes the trustee inter alia to "use" estate property outside the ordinary course of business, subject to court approval. A use of estate property might be to collateralize prepetition debt (cross-collateralization) or pay that debt (roll-up) as part of a DIP agreement. On the other hand, the proposed use of estate property under $\S 363$ might be authorized implicitly only when the use does not disturb Code priorities. ${ }^{57}$ Cross-

55. See Bankr. S.D.N.Y. R. 4001-2(a)(6), (7) (2017) (“material provisions"); Bankr. D. Del. R. 4001-2(a)(i)(A), (E) (2009) ("provisions to be highlighted").

56. See, e.g., Shapiro v. Saybrook Mfg. Co. (In re Saybrook Mfg. Co.), 963 F.2d 1490, 1495 (11th Cir. 1992) (noting that cross-collateralization is not authorized by 11 U.S.C. § 364); In re Willingham Invs., Inc., 203 B.R. 75, 78-79 (Bankr. M.D. Tenn. 1996).

57. Compare In re Saybrook, 963 F.2d at 1495 (stating that cross-collateralization is prohibited when it alters Bankruptcy Code priorities) with In re Kmart Corp., 359 F.3d 866, 872 (7th Cir. 2004) (allowing without deciding that 11 U.S.C. § 363(b)(1) might authorize critical vendor orders even when altering Code priorities). 
collateralization and roll-ups remain controversial in part because equally plausible but inconsistent inferences can be drawn from the section.

If the Code authorizes cross-collateralization and roll-ups, a legal standard must regulate their use in DIP financing agreements. In vetting financing agreements under $\S 364$, courts have taken into account a range of considerations. These include (1) whether the proposed financing is needed to preserve the estate and is in the interest of the debtor and its creditors, (2) whether the financing terms are reasonable in light of the circumstances of the debtor, and (3) whether the proposed financing was negotiated in good faith and at arm's length. ${ }^{58}$ In relying on these considerations, courts defer to the debtor's sound business judgment. ${ }^{59}$ The second consideration listed is significant. Financing terms that are in the interest of creditors (other than the DIP lender with prepetition claims) must benefit them or at least not make them worse off. This is the same standard to which Judge Easterbrook subjects critical vendor payments: the requirement that the proposed payment to the critical vendor have a "prospect of benefit" to the remaining creditors. ${ }^{60}$

The hard question in any particular case is whether crosscollateralization or a roll-up is expected to benefit creditors other than the DIP lender. Information necessary for a confident determination often is not available to bankruptcy courts called on to approve financing agreements with these terms. This is a problem because the terms can have conflicting potential impacts on the creditors' interests. On the one hand, a DIP loan enables the debtor to continue in business rather than liquidating. At the same time, financing terms that secure or give other priority to the DIP loan while collateralizing or paying off the lender's prepetition debt can leave the DIP lender unaffected by the use to which the debtor puts the loan proceeds. This can make the lender indifferent about the risks associated with the projects in which the debtor invests them. The debtor's continuation therefore might reduce the value of its assets and therefore decrease the distribution available to creditors. Thus, the effective priority in distribution resulting from cross-collateralization or a roll-up might harm disfavored creditors. On the other hand, a DIP loan enables the debtor to invest in projects potentially beneficial to its creditors. A lender with preexisting lending relationships with the debtor

58. See In re Constar Int'l Holdings LLC, No. 13-13281, 2013 WL 6832276, at *8-9 (Bankr. D. Del. 2013); Bland v. Farmworker Creditors, 308 B.R. 109, 113-14 (S.D. Ga. 2003) (mentioning the considerations).

59. See In re Allied Sys. Holdings, Inc., No. 12-11564, 2013 WL 12301177, at *2-3 (Bankr. D. Del. 2013); In re Ames Dep't Stores, Inc., 115 B.R. 34, 40 (Bankr. S.D.N.Y. 1990); In re Curlew Valley Assocs., 14 B.R. 506, 511-14 (Bankr. D. Utah 1981).

60. In re Kmart, 359 F.3d at 874 . 
might have private information about its prospects or otherwise be willing to lend on more favorable terms than other potential lenders. Crosscollateralization and roll-ups in turn can reduce debt servicing charges or be part of an otherwise favorably priced loan. In these circumstances the terms of the DIP agreement serve creditors' interests even when they give the DIP lender's prepetition debt effective priority over creditors' debt.

\section{Substantive Consolidation}

Many large firms partition their assets among legally separate entities, granting some creditors structural priority over others. ${ }^{61}$ If a corporate parent puts some of its assets in one of its subsidiaries, creditors who lend to the subsidiary get paid from the subsidiary's assets before creditors of the other affiliates get paid from them. Partitioning assets in different affiliates therefore in effect gives creditors of the subsidiary priority over creditors of the other affiliates. For example, assume that Bank lends $\$ 10$ to Parent and Finance lends $\$ 5$ to Subsidiary. In addition to owning all of the stock of Subsidiary, Parent has assets with a value of $\$ 5$, and Subsidiary's assets are valued at $\$ 8$. If both debtors default and their assets are liquidated, Finance receives $\$ 5$ from Subsidiary's assets. Bank receives $\$ 3$ (\$8 - \$5), the remaining value of Subsidiary's assets after Finance's claim is satisfied from them. Finance therefore is paid in full while Bank's total recovery is $\$ 8$ ( $\$ 3$ from Subsidiary's assets plus $\$ 5$ from Parent's assets).

Under prescribed conditions, bankruptcy law allows the assets of legally separate debtors to be consolidated. The doctrine of substantive consolidation, when applicable, combines the assets of the debtors and cancels any liabilities the debtors have to each other. Creditors' claims against the separate debtors are treated as claims against the consolidated estate and satisfied from it. Substantive consolidation can enhance the distribution of certain creditors at the expense of other creditors. In general, substantive consolidation enhances the recovery of the unsecured claims of the more insolvent consolidated debtor and diminishes the recovery of the unsecured claims of the less insolvent debtor. For example, assume that Debtor A has assets of $\$ 50$ and unsecured liabilities of $\$ 100$ while Debtor B has assets of $\$ 20$ and unsecured liabilities of $\$ 100$. Without consolidation, A's creditors receive a 50\% distribution from A's

61. See Reinier Kraakman et al., The Anatomy of Corporate law: A Comparative AND FUNCTIONAL APPROACH 9-10 (2d ed. 2009) (describing role of asset partitioning among legally separate entities in enabling pledge of assets just to creditors of each entity); DOUGLAS BAIRD, ELEMENTS OF BANKRUPTCY 253-54 (6th ed. 2014) (illustrating structural priority involving a corporate conglomerate). 
estate and B's creditors receive a $20 \%$ distribution from B's estate. If A's and B's assets are substantively consolidated, A's and B's creditors each receive a $35 \%$ distribution from the consolidated assets.

We view substantive consolidation as a deviation from equality. A simple definition of equality suggests precisely the opposite, because substantive consolidation results in each creditor receiving the same ratable distribution. To the extent this is true, however, it is an inequitable equality because creditors whose claims against their debtor were entitled to a pro rata distribution from a legally separate set of assets instead receive a pro rata distribution based on all of the claims against the consolidated debtors from the consolidated debtors' assets. Thus, consolidation enables creditors in the same class to receive more or less than they would receive from their respective debtor's estate. This deviation from the ordinary priority rules is an inequality if the relevant standard is "to each according to her distribution from her debtor's assets." In the previous example involving Bank and Finance, without substantive consolidation, Finance is the sole creditor of Subsidiary and is paid in full (\$5). Bank, whose claim is not paid in full, is entitled to a distribution from Subsidiary's assets only after Finance's claim has been satisfied from them. Bank's total distribution, as before, is $\$ 8$. By comparison, where Parent and Subsidiary's assets are substantively consolidated, Finance's pro rata distribution does not pay it in full $(\$ 5 / \$ 15 \times \$ 13=\$ 4.29)$. Bank's distribution is $\$ 8.58(\$ 10 / \$ 15 \times \$ 13)$. From the baseline of a distribution from their respective debtors' assets, Finance and Bank are treated unequally. ${ }^{62}$

The statutory authority for substantive consolidation is elusive. No Bankruptcy Code provision directly authorizes the practice, ${ }^{63}$ and none appears malleable enough to implicitly support it. Nonetheless, the

62. The choice of operative notion of equality is contestable. However, bankruptcy law does not guarantee creditors an equal distribution in satisfaction of their claims. On the notion of equality as equal ratable distribution, substantive consolidation allows courts to ignore the legal separateness of debtors and enforce an equal ratable distribution in bankruptcy. $C f$. Chem. Bank N.Y. Tr. Co. v. Kheel, 369 F.2d 845, 848 (2d Cir. 1966) (Friendly, J., concurring) (stating that equity allows consolidation). Courts commonly recite that substantive consolidation is an unusual equitable remedy to be used "sparingly." See Alexander v. Compton (In re Bonham), 229 F.3d 750, 767 (9th Cir. 2000); Kheel, 369 F.2d at 847 . This acknowledgment implicitly recognizes that, where equity does not allow consolidation, bankruptcy law might mandate an unequal distribution to creditors of different debtors.

63. Neither 11 U.S.C. § 105(a) nor the inherent jurisdiction of the bankruptcy (or district) court ground the power to substantively consolidate separate debtor's estates. The closest authority is 11 U.S.C. $§ 1123(\mathrm{a})(5)(C)$. However, a straightforward reading of that provision does not provide a basis to consolidate separate estates. By its terms, the provision permits a plan as implemented to include consolidation. Thus, $\S 1123(\mathrm{a})(5)(\mathrm{C})$ allows the plan to call for the merger of the reorganized debtor. The provision does not say or imply that the rights of creditors can be compromised by such a consolidation. 
practice is well entrenched in case law. Courts divide over the standard under which the assets and liabilities of legally distinct debtors can be consolidated. Although some courts are unclear about the basis on which they rely, ${ }^{64}$ the case law reveals two competing standards. The predominant standard requires that either of two conditions be met: (1) that the distinct debtors disregarded their separate identities so that creditors dealt with them as a single economic unit and did not rely on their separate identities, or (2) that the separate debtors' financial affairs have become so entangled that consolidation benefits all unsecured creditors. ${ }^{65} \mathrm{~A}$ minority of courts rely on a standard that permits substantive consolidation if (1) there is a substantial financial identity between the entities to be consolidated and (2) consolidation is needed to avoid some harm or realize some benefit to creditors. ${ }^{66}$ If the proponent shows both of these things, the burden of proof shifts to the opponent of consolidation. It must demonstrate that it relied on the separate credit of one of the entities and that it will be harmed by consolidation. ${ }^{67}$ Even if the disfavored creditor makes this showing, the court may still approve the substantive consolidation if "the demonstrated benefits of consolidation 'heavily' outweigh the harm." 68

The two competing standards are significantly different. The second part of the majority disjunctive standard allows consolidation only when it improves the position of every creditor or at least does not leave any worse off - a Pareto improvement. By contrast, the minority's standard requires only that consolidation avoid some harm or produce some benefit for the creditors. Importantly, it does not require that consolidation benefit every creditor. ${ }^{69}$ Thus, the standard allows consolidation when, although harming some creditors, results in a net benefit for creditors as a whole. For example, the D.C Circuit would allow substantive consolidation as long as "the demonstrated benefits of consolidation 'heavily' outweigh the harm." $" 70$ This is a Kaldor-Hicks test.

64. See, e.g., In re Owens Corning, 419 F.3d 195, 207 (3d Cir. 2005) (stating that most courts "slipstreamed" behind different rationales).

65. See id. at 208-09; United Savs. Bank v. Augie/Restivo Baking Co. (In re Augie/Restivo Baking Co.), 860 F.2d 515, 518 (2d Cir. 1988).

66. See Eastgroup Props. v. S. Motel Assoc., 935 F.2d 245, 249 (11th Cir. 1991); Drabkin v. Midland-Ross Corp. (In re Auto-Train Corp.), 810 F.2d 270, 276 (D.C. Cir. 1987).

67. See Eastgroup Props., 935 F.2d at 249; In re Auto-Train Corp., 810 F.2d at 276.

68. Eastgroup Props., 935 F.2d at 249 (citation omitted).

69. Some courts have been fairly liberal in finding a benefit from consolidation. See, e.g., In re Owens Corning, 305 B.R. at 181-82.

70. In re Auto-Train Corp., 810 F.2d at 276 (citation omitted). 


\section{HOW FREQUENT ARE PRIORITY DEVIATIONS?}

A number of commentators have suggested that critical vendor orders, roll-ups and substantive consolidation are quite common. The literature offers at least some limited evidence on their frequency. Tung presents the most recent and most thorough study of roll-ups. He studies all firms that filed for bankruptcy between 2012 and 2014, had their bankruptcy resolved by 2013, and are listed in Lynne LoPucki's Bankruptcy Research Database. ${ }^{71} \mathrm{He}$ found that $62 \%$ of the cases had DIP financing and that of these more than half (54\%) had a roll-up. ${ }^{72}$ Although roll-ups sometimes are classified as "extraordinary provisions" and justified by arguing that the debtor would not otherwise be able to get credit, Tung fails to find a statistically significant relationship between roll-ups and economic conditions. ${ }^{73}$ William Widen also used LoPucki's Bankruptcy Research Database to study substantive consolidation. ${ }^{74}$ He found that that more than half $(56.5 \%)$ of the firms in this database that filed between 2000 and 2005 had some form of substantive consolidation. ${ }^{75}$ While the Tung and Widen studies are impressive, they look at a fairly narrow set of cases. To be included in LoPucki's Bankruptcy Research Database, a firm must be publicly traded and have assets of at least $\$ 100$ million in 1980 dollars, about $\$ 300$ million in 2017 dollars. $^{76}$ These bankruptcies account for a very small share of Chapter 11 filings. The Administrative Office of the U.S. Courts reports 7,241 Chapter 11 filings in 2015, but LoPucki's database lists just 25 firms for that year. ${ }^{77}$ Nonetheless, we understand the

\footnotetext{
71. See Tung, supra note 53, at 15.

72. Id. at $15,26$.

73. Id. at 2 .

74. See generally William H. Widen, Report to the American Bankruptcy Institute: Prevalence of Substantive Consolidation in Large Public Company Bankruptcies from 2000 to 2005, 16 AM. BANKR. INST. L. REV. 1 (2008) (using the LoPucki database in a study of substantive consolidation in large public bankruptcy filings).

75. Id. at 5 .

76. \$100 million in June of 1980 is $\$ 296$ million in June of 2017. UCLA-LoPucki Bankruptcy Research Database, UCLA SCH. L., http://lopucki.law.ucla.edu/ (last visitied March 14, 2018); see also CPI Inflation Calculator, BUREAU LAB. STAT., https://www.bls.gov/data/ inflation_calculator.htm (last visited March 14, 2018).

77. Table F-2-Bankr. Filing, U.S. CouRTs, http://www.uscourts.gov/sites/default/files/table _f-_2_yearly_dec_2015_0.pdf (Dec. 31, 2015); UCLA-LoPucki Bankruptcy Research Database, supra note 76. Nearly all of these firms had multiple subsidiaries that filed their own bankruptcy petitions and thus were counted as separate cases by the Administrative Office. As a result, the public firms would account for many more than 25 cases out of 7,241. For a discussion of firms and cases, see infra note 95 and accompanying text.
} 
need to study large dollar bankruptcies. To paraphrase Willie Sutton, that is where the money is. ${ }^{78}$

Our search of the literature found allegations that courts routinely approve critical vendor orders paying little attention to the standards set forth in $\mathrm{Kmart}^{79}$ and that the approval of these orders is becoming increasingly common. ${ }^{80}$ With one exception, the academics making these allegations present no data to support these claims. The exception is a recent study of sixty-three large Chapter 11 cases filed in 2013. ${ }^{81}$ The study found that critical vendor orders were filed and approved in approximately $75 \%$ of the cases. ${ }^{82}$ Unfortunately, it is unclear what general lessons one can draw from these cases because the study provides few details as to how the sample was constructed. Unlike LoPucki's sample that has clear criteria for inclusion, the study of sixty-three Chapter 11 cases tells us only that the data was provided by "leading claims agents in large Chapter 11 cases." 83 Moreover, the cases selected were almost certainly not a random sample of the cases handled by these firms because it included the ten largest bankruptcies from that year, ${ }^{84}$ and the study does not tell us whether the sample represents the full population of cases handled by these firms. Finally, the source of the data suggests that the study did not sample small firm bankruptcy reorganizations.

Although we do not provide a thorough empirical study of critical vendor orders, the suggestive evidence we present begins to fill an important gap in the literature and suggests four tentative conclusions. First, critical vendor orders do occur, but they are by no means universal. The majority of firms in Chapter 11 do not appear to pay prepetition creditors prior to plan confirmation or liquidation. Second, size matters: critical vendor orders are much more common in the reorganization of

78. Leonard Buder, Willie Sutton Said It First: 'That's Where the Money Is,' N.Y. TIMES, http://www.nytimes.com/1979/08/26/archives/willie-sutton-said-it-first-thats-where-the-moneyis.html (last visited Feb. 14, 2018). Willie Sutton is alleged to have explained that he robbed banks "because that's where the money is." Id.

79. See, e.g., Mark J. Roe \& Frederick Tung, Breaking Bankruptcy Priority: How Rent-Seeking Upends the Creditors' Bargain, 99 VA. L. REV. 1235, 1257 (2013) ("In practice, few lower courts expend much energy making the judgments that the Seventh Circuit thought appropriate. Debtors ask that the old vendors be paid and courts approve those requests."); Skeel, supra note 1, at 717 ("Bankruptcy judges rarely require a debtor to present any meaningful evidence that a supplier truly is irreplaceable and would cease doing business with the debtor unless it is paid in full.").

80. Skeel, supra note 1, at 717 ("Critical vendor treatment traditionally was viewed as a limited exception to the equality of creditors norm, but its use is now commonplace in large cases.").

81. See Elizabeth Shumejda, Critical Vendor Trade Agreements in Chapter 11 Bankruptcy, 24 AM. BANKR. INST. L. REV. 159, 160 (2016).

82. See id.

83. Id. at 171

84. Id. at $220 \mathrm{n} .54$. 
larger firms than in smaller firms. Third, many critical vendor orders authorize payments to creditors who are likely to otherwise enjoy priority over general creditors. Fourth, we fail to find a discernable increase in these orders between 2008 and 2015.

With our research assistants, we began by reading the dockets of two (admittedly small) samples of cases to identify the language courts used for critical vendor orders. First, we looked at cases in LoPucki's Bankruptcy Research Database that filed in 2015. We chose to look at cases filed in 2015 because these cases are recent but still have had sufficient time for critical vendor motions to occur. Because there were just twenty-five of these cases, we had a research assistant examine every one. In addition, we had a research assistant examine a random sample of thirty corporate Chapter 11 cases filed in either 2010 or 2013 in jurisdictions that account for about $93 \%$ of all Chapter 11 filings in the United States. ${ }^{85}$ Because we are interested in the percentage of bankrupt "firms" that have critical vendor orders, we dropped a case if it was consolidated with another case. ${ }^{86}$

Both searches faced the same definitional problem of what precisely we mean by a critical vendor order. One can plausibly argue that payments to creditors that enjoy priority are different than payments to general unsecured creditors. As noted above, vendors who delivered goods within the ordinary course of business are given administrative expense status under $\S 503(b)(9)$, some taxes are given priority over general claims, ${ }^{87}$ and workers claims for unpaid wages and employee benefits are given priority as long as they are below some dollar amounts. ${ }^{88}$ Other creditors, such as shippers and warehousemen, sometimes can assert liens on the debtor's goods in their possession. ${ }^{89}$ To the extent that these creditors would be entitled to priority over general creditors in a liquidation or reorganization, general unsecured creditors have less reason to object to their early repayment. On the other hand, these provisions give the creditors priority at the end of a case, not a right to immediate payment. Moreover, it is not always so clear whether the creditors actually enjoy priority. For example, a shipper may have a plausible claim to a lien, but this lien could be subordinate to a priority lien of a secured creditor and fully underwater.

85. See Richard M. Hynes, Anne Lawton \& Margaret Howard, National Study of Individual Chapter 11 Bankruptcies, 25 AM. BANKR. INST. L. REV. 61, 69 n. 40 (2017) (listing the few jurisdictions that were excluded from the study).

86. Failing to do so would overweight firms with many subsidiaries. For example, if firm A has a parent and nine subsidiaries and firm B has just a single corporation, coding the lead case would give firm A ten times the odds of inclusion as firm B.

87. See 11 U.S.C. $\S 507(a)(8)$ (2012).

88. See id. $\S 507(\mathrm{a})(4),(5)$.

89. See U.C.C. § 7-209 (AM. L. INST. \& UNIF. LAW COMM'N 2003). 
Similarly, the claims of some workers may exceed the dollar limits, and general creditors could argue that some goods were not delivered in the ordinary course of business. It can be controversial whether a payment to priority creditor should count as a critical vendor payment and unclear whether a critical vendor payment is a priority payment or a payment to a general creditor.

Because of this uncertainty, we considered two measures. Our "broad" measure includes any identifiable repayment of a pre-petition claim. Our "narrow" measure excludes payments of claims that have some plausible claim to priority, such as employee claims for wages and employee benefits, claims for unpaid taxes, claims designated as $\S$ 503(b)(9) claims, claims of shippers and warehousemen, and claims where there is a plausible argument for a constructive trust. We assessed the priority of the claims based solely on the information on the docket itself.

Regardless of how we measured critical vendor orders, they were much more common in the larger bankruptcies in the LoPucki's Bankruptcy Research Database. Twenty-three of the twenty-five publicly traded firms (92\%) had a broadly defined critical vendor order; the only two for which we could not find a payment of a pre-petition debt were involuntary filings. If we limit our definition of a critical vendor order to payments of claims without some assertion of priority, this rate falls to fourteen out of twenty-five firms (56\%), as a few firms paid wages and other employee obligations and many of the energy firms asserted that the paid claims would have enjoyed some form of priority. These figures were much higher than those we found in the random sample of Chapter 11 cases. Of the thirty randomly selected Chapter 11 bankruptcies filed in 2010 or $2013,16.7 \%$ had a broadly defined critical vendor order and only two $(6.7 \%)$ had a narrowly defined critical vendor order.

Unfortunately, neither sample is entirely satisfactory. The random sample should be fairly representative of Chapter 11 cases. However, because small firm filings constitute most of the Chapter 11 cases filed, the sample is dominated by smaller cases. Only half of the Chapter 11 cases in our random sample had more than a million dollars in liabilities and just $40 \%$ had more than a million dollars in assets. The LoPucki sample presents the opposite problem. It focuses on the most massive bankruptcies, but comprises a small share of all Chapter 11 filings. We mitigated these problems by searching all dockets on Bloomberg Law for Chapter 11 cases filed between 2008 and 2015. ${ }^{90}$

90. We did not search cases after 2015 because we wanted to allow for a delay in Bloomberg's gathering of dockets. We did not search prior to 2008 because of concern about the completeness of Bloomberg's coverage. 
Bloomberg Law periodically downloads the bankruptcy dockets found in the federal courts' database, PACER. Bloomberg law allows the user to search by bankruptcy chapter, but following PACER, it records the active bankruptcy chapter or the bankruptcy chapter in which the case terminated. As a result, our searches miss those cases that were filed in Chapter 11 but later converted to Chapter 7 . To get a sense of the importance of this limitation, consider that the Administrative Office of the U.S. Courts reports that there were 8,980 Chapter 11 cases in 2013, ${ }^{91}$ but a search of Bloomberg Law for all Chapter 11 cases filed in 2013 yields just 7,494 cases.

Bloomberg Law gives the user the ability to search by asset size with cut-offs at $\$ 100,000, \$ 1,000,000$ and $\$ 100,000,000$. It does not, however, allow the user to limit the search to corporate debtors, and individuals account for a substantial share of Chapter 11 filings. ${ }^{92}$ To limit the impact of individual filings, and to exclude extremely small businesses that may not have had significant trade debt, we ignored cases with less than $\$ 1,000,000$ in assets. We further divided our sample between those cases with over $\$ 100,000,000$ in assets and those with assets between $\$ 1,000,000$ and $\$ 100,000,000$. Most Chapter 11 cases have few valuable assets; omitting the small cases dropped our 2013 sample down to 3,523 cases, 516 with more than $\$ 100$ million in assets and 3,007 with between $\$ 1$ million and \$100 million. ${ }^{93}$

We conducted two searches. Search 1 looked for dockets with some derivation of the phrase "critical vendor." More specifically, Search 1 looked for "(critical or essential) /4 (vendor or vendors)." Unfortunately, debtors may not always use the phrase "critical vendor" when seeking permission to pay a favored creditor. Search 2 was therefore much broader, "((pay or payment) $/ 4$ (prepetition or (pre $/ 3$ petition)) or ((critical or essential) /4 (vendor or vendors)) or 503(b)(9)." Table 1 summarizes the results.

\footnotetext{
91. Table F-2-Bankr. Filing, supra note 77.

92. See Hynes, Lawton \& Howard, supra note 85, at 1 (finding that individuals account for more than a quarter of Chapter 11 filings).

93. Some of the missing firms simply had no asset value reported. To get a sense of how many, we searched the cases from December of 2013. There appeared to be 256 cases with less than $\$ 1$ million and 33 cases with no estimation of assets.
} 
Table 1: Critical Vendor Orders in Bankruptcy Cases

\begin{tabular}{|l|l|l|l|l|l|l|}
\cline { 2 - 7 } \multicolumn{1}{c|}{} & \multicolumn{2}{l|}{ Total Cases } & \multicolumn{2}{l|}{ CVOs in Search 1 } & \multicolumn{2}{l|}{ CVOs in Search 2 } \\
\cline { 2 - 7 } \multicolumn{1}{c|}{} & $\mathbf{1 - 1 0 0 M}$ & $\mathbf{1 0 0 M +}$ & $\mathbf{1 - 1 0 0 M}$ & $\mathbf{1 0 0 M +}$ & $\mathbf{1 - 1 0 0 M}$ & $\mathbf{1 0 0 M +}$ \\
\hline $\mathbf{2 0 0 8}$ & 2,616 & 806 & $51(1.9 \%)$ & $24(3.0 \%)$ & $337(12.9 \%)$ & $87(10.8 \%)$ \\
\hline $\mathbf{2 0 0 9}$ & 3,943 & 2,038 & $85(2.2 \%)$ & $59(2.9 \%)$ & $567(14.4 \%)$ & $138(6.8 \%)$ \\
\hline $\mathbf{2 0 1 0}$ & 3,838 & 886 & $101(2.6 \%)$ & $21(2.4 \%)$ & $548(14.3 \%)$ & $61(6.9 \%)$ \\
\hline $\mathbf{2 0 1 1}$ & 3,568 & 335 & $76(2.1 \%)$ & $25(7.5 \%)$ & $456(12.8 \%)$ & $58(17.3 \%)$ \\
\hline $\mathbf{2 0 1 2}$ & 3,038 & 558 & $73(2.4 \%)$ & $20(3.6 \%)$ & $381(12.5 \%)$ & $42(7.5 \%)$ \\
\hline $\mathbf{2 0 1 3}$ & 3,007 & 516 & $62(2.1 \%)$ & $12(2.3 \%)$ & $371(12.3 \%)$ & $40(7.8 \%)$ \\
\hline $\mathbf{2 0 1 4}$ & 2,240 & 390 & $53(2.4 \%)$ & $17(4.4 \%)$ & $331(14.8 \%)$ & $37(9.5 \%)$ \\
\hline $\mathbf{2 0 1 5}$ & 2,126 & 588 & $80(3.8 \%)$ & $18(3.1 \%)$ & $338(15.9 \%)$ & $63(10.7 \%)$ \\
\hline Total & 24,376 & 6,117 & $581(2.4 \%)$ & $196(3.2 \%)$ & $3,329(13.7 \%)$ & $526(8.6 \%)$ \\
\hline
\end{tabular}

As one would expect, Search 2 found many more possible critical vendor orders than Search 1, but some of these could be false positives. For example, Search 2 could pick up a motion to recognize administrative expense status under $\S 506(\mathrm{~b})(9)$. If one adopts our broad definition of a critical vendor order (any repayment of a pre-petition debt prior to confirmation), false positives do not appear to be a significant concern. We randomly selected thirty cases identified by Search 2 in each of the two data sets ( $\$ 1$ million to $\$ 100$ million and over $\$ 100$ million), and 97\% of each (29/30) had a broadly defined critical vendor order. The results were quite different for the narrow definition of a critical vendor order (repayment of a prepetition debt with no asserted claim to priority). Just $47 \%(14 / 30)$ of the cases with more than $\$ 100$ million in assets had a narrowly defined critical vendor order, and just 17\% (5/30) of the smaller cases had such an order.

Table 1 suggests rates of critical vendor orders that are quite low relative to the searches of the random sample and the large pubic company bankruptcies. However, this result is misleading because of the difference between a firm and a corporation. Most large firms are comprised of many separate legal entities. When the firm files for bankruptcy, each legal entity files its own bankruptcy petition that is counted as a separate case by the Administrative Office of the U.S. Courts. Such firms will usually ask the court to administratively consolidate or jointly administer the various cases, and the bankruptcy dockets of the consolidated cases will typically tell the reader to consult the lead case for all motions made after the consolidation. Thus, because the motion for a critical vendor order 
may be listed only on the lead case, the percentage of cases with a critical vendor order on their dockets may understate the true prevelance of these orders. ${ }^{94}$ To address this problem, we adopted an expedient method of estimating the number of bankrupt firms. We assumed two cases were consolidated if they were listed sequentially-by filing date- and assigned to the same bankruptcy judge. Table 2 presents the results.

Table 2: Critical Vendor Orders in Bankrupt "Firms"

\begin{tabular}{|l|l|l|l|l|l|l|}
\cline { 2 - 7 } \multicolumn{1}{c|}{} & \multicolumn{2}{l|}{ Total "Firms" } & \multicolumn{2}{l|}{ CVOs in Search 1 } & \multicolumn{2}{l|}{ CVOs in Search 2 } \\
\cline { 2 - 7 } \multicolumn{1}{c|}{} & $\begin{array}{l}\mathbf{1 -} \\
\mathbf{1 0 0 M}\end{array}$ & $\mathbf{1 0 0 M +}$ & $\mathbf{1 - 1 0 0 M}$ & $\mathbf{1 0 0 M +}$ & $\mathbf{1 - 1 0 0 M}$ & $\mathbf{1 0 0 M +}$ \\
\hline $\mathbf{2 0 0 8}$ & 1,911 & 160 & $38(2.0 \%)$ & $22(13.8 \%)$ & $275(14.4 \%)$ & $81(50.6 \%)$ \\
\hline $\mathbf{2 0 0 9}$ & 2,898 & 294 & $82(2.8 \%)$ & $58(19.7 \%)$ & $490(16.9 \%)$ & $133(45.2 \%)$ \\
\hline $\mathbf{2 0 1 0}$ & 2,960 & 119 & $96(3.2 \%)$ & $21(17.6 \%)$ & $478(16.1 \%)$ & $56(47.1 \%)$ \\
\hline $\mathbf{2 0 1 1}$ & 2,990 & 89 & $63(2.1 \%)$ & $23(25.8 \%)$ & $399(13.3 \%)$ & $49(55.1 \%)$ \\
\hline $\mathbf{2 0 1 2}$ & 2,467 & 76 & $68(2.8 \%)$ & $20(26.3 \%)$ & $350(14.2 \%)$ & $41(53.9 \%)$ \\
\hline $\mathbf{2 0 1 3}$ & 2,476 & 64 & $55(2.2 \%)$ & $11(17.2 \%)$ & $339(13.7 \%)$ & $37(57.8 \%)$ \\
\hline $\mathbf{2 0 1 4}$ & 1,860 & 67 & $51(2.7 \%)$ & $17(25.4 \%)$ & $289(15.5 \%)$ & $37(55.2 \%)$ \\
\hline $\mathbf{2 0 1 5}$ & 1,695 & 82 & $68(4.0 \%)$ & $16(19.5 \%)$ & $295(17.4 \%)$ & $42(51.2 \%)$ \\
\hline Total & 19,257 & 951 & $521(2.7 \%)$ & $188(19.8 \%)$ & $2,915(15.1 \%)$ & $476(50.1 \%)$ \\
\hline
\end{tabular}

Our expedient method of estimating "firms" adds an additional source of error. Based on our search of random samples of cases, we are fairly confident that we did not dramatically underestimate the number of independent firms. ${ }^{95}$ In fact, we may have substantially overestimated the number of firms with less than $\$ 100$ million in assets because we were not able to exclude individual filings. Although we restricted our attention to cases with more than $\$ 1$ million in assets, 37\% (11/30) of a random sample of independent cases with assets between $\$ 1$ million and $\$ 100$ million

94. Note that this was not a problem for a random sample of Chapter 11 cases and the sample of large public company bankruptcies above because we simply ignored those cases that were consolidated into another case.

95. Among the cases that our method identified as converted into another case, we randomly selected thirty with assets between $\$ 1$ million and \$100 million and thirty with assets in excess of $\$ 100$ million. Of those with less than $\$ 100$ million in assets, only two were actually independent cases. However, eight were consolidated with a case with more than $\$ 100$ million in assets and one was consolidated with a case with less than $\$ 1$ million in assets. Of the cases with more than $\$ 100$ million in assets, none were independent. However, two were consolidated into cases with less than $\$ 100$ million in assets, and one was consolidated into a case that converted into Chapter 7. 
were filed by individuals. ${ }^{96}$ Notably, our searchs of samples of cases identified as having critical vendor orders yielded no cases filed by individuals.

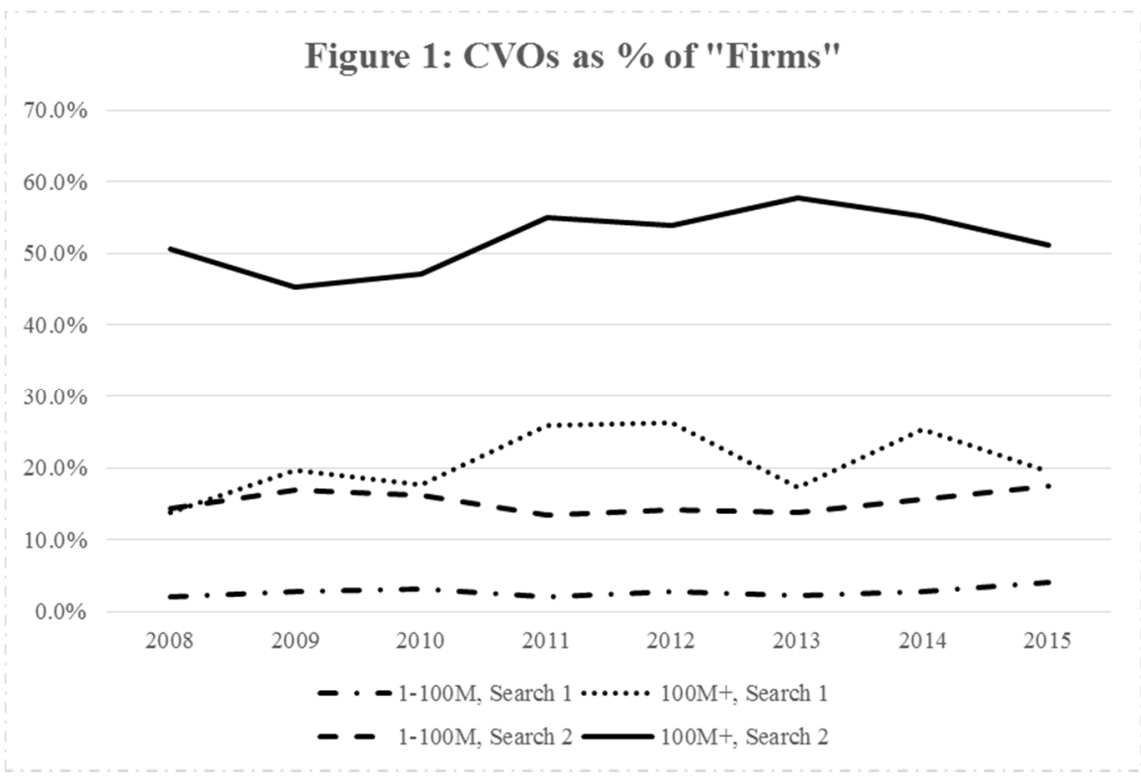

Although we caution against relying on our precise estimates, our results suggest that more thorough research would likely still reach four conclusions. First, critical vendor orders do occur, but they are by no means universal. Our random sample of firms in Chapter 11 found that less than $17 \%$ of cases had critical vendor orders, broadly defined, and we estimated a similar $20 \%$ for "firms" in our $\$ 1$ million to $\$ 100$ million Bloomberg sample. Second, many critical vendor orders authorize payment to creditors who might otherwise enjoy priority over general creditors. For example, the percentage of the random sample with critical vendor orders drops below 7\% if one excludes repayment of creditors who claim priority. Third, it does not appear that the use of these orders has been strongly increasing over the last decade. To demonstrate this, Figure 1 presents the information in Table 2 graphically. Although some of the lines do have positive slopes, the slopes are quite gradual. Fourth, these

96. This rate is even higher than that found by Hynes, Lawton, and Howard. See Hynes, Lawton, and Howard, supra note 85, at 11 (finding that individuals accounted for about thirty percent of Chapter 11 cases). One reason for this discrepancy is that the ABI project looked at individual filings as a percentage of cases while this figure lists individuals as a percentage of independent cases, and corporate bankruptcies are much more likely to be consolidated. Id. at 30 (finding that individual Chapter $11 \mathrm{~s}$ are rarely administratively or substantively consolidated). 
orders appear to be much more common in the very largest bankruptcies. For example, even if we restrict our attention to the repayment of general creditors, more than $56 \%$ of the large, public company bankruptcies filed in 2015 had a narrowly defined critical vendor order while just $7 \%$ of our random sample of Chapter 11 bankruptcies had such an order. Similarly, $20 \%$ of "firms" in our $\$ 1$ million to $\$ 100$ million Bloomberg sample had a critical vendor revealed by Search 2 while over half of "firms" in our over $\$ 100$ million Bloomberg sample had such an order.

Our research has important limitations. For example, we did not try to determine whether the recipients of the payments had a valid claim to priority or whether courts carefully scrutinized the debtor's assertions that the vendors were critical. ${ }^{97}$ We also did not try to determine the significance of the payments by, for example, comparing the dollar amount distributed to the total assets available for distribution to unsecured creditors.

Despite these limitations, our tentative results still raise interesting questions. One is why critical vendor orders are much more frequent in large firm bankruptcies than in comparatively small ones. ${ }^{98}$ This could be due to differences in the large firms' asset configurations, the industries in which these firms operate, or simply in the legal strategies pursued by large firms' bankruptcy lawyers. For example, there may be little reason to make a critical vendor payment if the debtor plans to liquidate.

Another question is why the frequency of critical vendor orders do not vary more sharply across time. In a study of roll-ups, Tung argues that he should have found a decrease in the use of roll-ups after the end of the recession because credit became more available and roll-ups should therefore have become less necessary for a firm to obtain debtor-inpossession financing. ${ }^{99}$ A similar argument might be made for critical vendor orders. One compelling rationale for a critical vendor payment is that the critical vendor is itself financially distressed and may go out of business if not repaid. This contention is more compelling during a recession or industry-wide financial stress.

97. Shumejda found that in none of her sixty-three cases was a request for a critical vendor order denied. See Shumejda, supra note 81, at 170.

98. This remains true even if one accounts for the prevalence of individual filings in the $\$ 1$ million to $\$ 100$ million Bloomberg sample.

99. See Tung, supra note 53, at 26. 


\section{IS THE PARETO STANDARD THE RIGHT TEST?}

Part I demonstrates that courts routinely adopt tests that require a Pareto improvement to allow a deviation from bankruptcy's standard priority rules. However, there are alternatives. A few courts have simply refused to allow deviations, ${ }^{100}$ and scholars argue that most courts do not take the existing (Pareto) tests seriously. ${ }^{101}$ Section A describes what economists mean by Pareto efficiency in more detail as well as its primary alternative in the economic analysis of public policy: Kaldor-Hicks efficiency. Section B explains why courts are naturally drawn to Pareto efficiency when formulating legal rules that apply when protecting property rights in bankruptcy. Section $\mathrm{C}$ describes the most significant shortcoming of requiring a Pareto improvement: it can prevent deviations that maximize the value of the estate. Section D describes some offsetting benefits of requiring a Pareto improvement.

\section{A. Pareto and Kaldor-Hicks Improvements}

Pareto efficiency or Pareto optimality is a standard tool in the economic analysis of public policy. ${ }^{102}$ An allocation or policy choice is not Pareto optimal if there is some reallocation of resources or other policy choice that would be a Pareto improvement. An outcome is a Pareto improvement or Pareto superior if someone is better off and no one is worse off. ${ }^{103}$ The Kmart test described above requires a Pareto improvement for a deviation from priority as it requires that the deviation "at least leave [the disfavored creditors] no worse off." "104 That is, the

100. See, e.g., In re Saybrook Mfg. Co., 963 F.2d 1490, 1495-96 (11th Cir. 1992); Official Comm. of Equity Sec. Holders v. Mabey, 832 F.2d 299, 302 (4th Cir. 1987); In re Tenney Vill. Co., 104 B.R. 562, 564-70 (Bankr. D. N.H. 1989); In re Monach Circuit Indus., Inc., 41 B.R. 859, 862 (Bankr. E.D. Pa. 1984)

101. See Skeel, supra note 1, at 717 ("Bankruptcy judges rarely require a debtor to present any meaningful evidence that a supplier truly is irreplaceable and would cease doing business with the debtor unless it is paid in full."); Roe \& Tung, supra note 79, at 1257 ("In practice, few lower courts expend much energy making the judgments that the Seventh Circuit thought appropriate. Debtors ask that the old vendors be paid and courts approve those requests").

102. See AmARTYA SEN, IneQuality ReEXAMINED 136 (1992) ("Pareto optimality is almost certainly the most widely used criterion in modern welfare economics.").

103. See Julian Le Grand, Equity and Choice: An Essay in Economics and Applied Philosophy 32 (1991); Amartya K. Sen, Collective Choice and Social Welfare 21 (1970). There are two different Pareto standards: strong and weak. The strong Pareto test counts an outcome a Pareto improvement if it makes at least one person better off and no person worse off than the status quo ante. See Per-Olov Johansson, An Introduction to Modern Welfare Economics 10 (1991). A "weak" Pareto standard counts an outcome as a Pareto improvement only if it makes all people better off. See id. The Pareto standard described in the text states a strong Pareto test.

104. In re Kmart Corp., 359 F.3d 866, 873 (7th Cir. 2004). 
Kmart test would not allow a deviation from the standard priority rules unless the standard rules are not Pareto optimal.

In Czyzewiski v. Jevic Holding Corp., ${ }^{105}$ the Supreme Court used language that an economist would recognize as weak Pareto efficiency. ${ }^{106}$ That is, the Supreme Court would allow a deviation from the standard rules only if the deviation is strictly preferred by all parties. ${ }^{107}$ According to the Court not only must the deviation leave the disfavored creditors no worse off, it must "make even the disfavored creditors better off." 108 Most tests for substantive consolidation also require a Pareto improvement. For example, the Second Circuit insists that "consolidation will benefit all creditors" 109 and the Third Circuit insists that "separating [the entities] is prohibitive and hurts all creditors." 110

In a Coaseian world without transaction costs, ${ }^{111}$ policymakers would not need a concept of Pareto optimality. Indeed, policymakers would not need to do much at all. If a reallocation or policy change were a Pareto improvement, the parties would voluntarily adopt the change through bargaining. Policymakers need only intervene if there are some frictions that make this bargaining impossible. But frictions can also limit the usefulness of Pareto efficiency. Too many allocations can be described as Pareto optimal because most policy choices will leave at least one person worse off. Consider a somewhat whimsical example. Assume aliens offer a cure for cancer for free. Accepting this cure would almost certainly not be a Pareto improvement. Drug companies would see the value of their patented cancer drugs fall, and some cancer specialists would see a sharp decline in the value of their human capital. The gain from a cure from cancer would be enormous, and society could, in theory, compensate the losers so that the change was a Pareto improvement. However, this can be difficult in practice as it is sometimes hard to identify the losers and determine how much they lost.

Economists therefore sometimes use a refinement of Pareto efficiency: Kaldor-Hicks efficiency. An allocation is a Kaldor-Hicks improvement if the winners gain sufficiently more than the losers lose so that the winners could hypothetically compensate the losers and still come

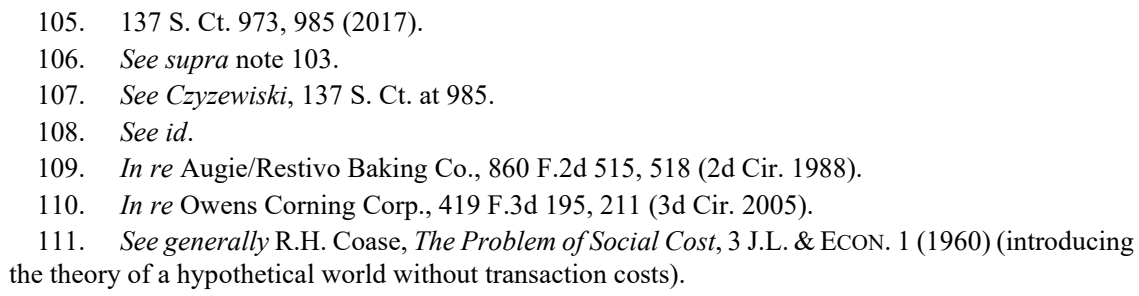


out ahead. ${ }^{112}$ A cure for cancer, for example, would be a Kaldor-Hicks improvement, as the benefits of this cure would surely be greater than its costs. The allocation is Kaldor-Hicks efficient if no further Kaldor-Hicks improvement can be made. ${ }^{113}$ The D.C. Circuit's test for substantive consolidation requires a Kaldor-Hicks improvement, as it insists that "the demonstrated benefits of consolidation 'heavily' outweigh the harm." "114 A Kaldor-Hicks improvement does not, however, require that the compensation take place. ${ }^{115}$ As a result, it is indifferent to distribution and the original allocation of entitlements.

\section{B. Property Rights and the Pareto Improvements in Bankruptcy}

Outside bankruptcy, courts protect property rights with either property rules or liability rules. ${ }^{116}$ A property rule allows the property owner to set the terms under which its property can used by others. ${ }^{117}$ The owner therefore fixes the price, if any, it is willing to accept for that use. ${ }^{118}$ By contrast, a liability rule allows a third party, such as a court, to set the compensation owed for use of the property. ${ }^{119}$ For example, if the government wishes to take property by eminent domain, it must pay compensatory damages determined after the taking. ${ }^{120}$ This is a liability rule. The government can take property as long as it is willing to pay the owner an amount set by the court. Similarly, someone who accidentally damages your car must pay compensatory damages determined after the fact. However, nonbankruptcy law generally does not allow non-owners to seek permission to intentionally damage property in advance at a price to be set by the court, and someone who intentionally infringes upon the

112. See William J. Baumol, ECONOmic Theory and OPerations Analysis 378 ( $2 \mathrm{~d}$ ed. 1965); J.R. Hicks, The Foundations of Welfare Economics, 49 ECON. J. 696 (1939); Nicholas Kaldor, Welfare Propositions of Economic and Interpersonal Comparisons of Utility, 49 ECON. J. 549 (1939).

113. See Hicks, supra note 112, at 701.

114. In re Auto-Train Corp., 810 F.2d 270, 276 (D.C. Cir. 1987).

115. Both Kaldor and Hicks themselves took the question of actual compensation to be a separate question. See Kaldor, supra note 112, at 550 ("Whether the landlords [i.e., the losers], in the freetrade case, should in fact be given compensation or not, is a political question, on which the economist, qua economist, could hardly pronounce an opinion."); Hicks, supra note 112, at 711 (“[W] hether or not compensation should be given in any particular case is a question of distribution, upon which there cannot be identity of interest, and so there cannot be any generally acceptable principle.").

116. See generally Guido Calabresi \& A. Douglas Melamed, Property Rules, Liability Rules, and Inalienability: One View of the Cathedral, 85 HARV. L. REV. 1089 (1972) (discussing the intersection of property rules and liability rules).

117. Id. at 1092 .

118. Seeid.

119. See id. at 1092-93.

120. See infra note 150 . 
property of another may face punitive damages and imprisonment. ${ }^{121}$ This protection of entitlements is called a "property rule" because it requires the consent of the property owner, preserving the right of the property owner (not the court or the non-owner) to determine how the property will be used. ${ }^{122}$ Unlike a liability rule, a property rule enables the owner to set the price for its use.

Bankruptcy substantially weakens the ability of property owners to determine how their assets are used. One extreme example is In re Plastech Engineered Products, Inc. ${ }^{123}$ Plastech supplied parts to Chrysler using tools purportedly owned by Chrysler. ${ }^{124}$ When Chrysler tried to terminate the relationship and exercise its right to retrieve the tools, Plastech filed for bankruptcy. ${ }^{125}$ The bankruptcy court decided that because Plastech had a mere possessory interest in the tools (they were located at its plant), it could continue to use them against Chrysler's wishes if it offered Chrysler "adequate protection." 126

Someone who has an interest in property that the debtor intends to use, sell or lease can demand adequate protection. ${ }^{127}$ A debtor's failure to provide adequate protection is grounds for lifting bankruptcy's automatic stay and allowing repossession of the property. ${ }^{128}$ Adequate protection is designed to protect the owner against the risk that the value of her property will decline. ${ }^{129}$ Sometimes this will require payments to compensate for the depreciation. ${ }^{130}$ Sometimes adequate protection will require replacement security. ${ }^{131}$ Sometimes the court will say nothing additional is needed. ${ }^{132}$ One can think of adequate protection as an approximation of

121. See CAL. Penal Code $\S 601$ (West 2010, Supp. 2014) (criminal trespass of residence, real property or workplace punishable by imprisonment or fine); GA. CODE ANN. § 16-7-21 (West 2009) (criminal trespass punishable as a misdemeanor); Jacque v. Steenberg Homes, Inc., 563 N.W.2d 154, 159 (Wis. 1997) (explaining the need for punitive damages even where the actual harm is slight); RESTATEMENT (SECOND) OF TORTS $§ 163 \mathrm{cmt}$. e (AM. LAW. INST. 1965) (explaining that punitive damages are recoverable for harmless trespass on land when trespass is in complete disregard of owner's property interest).

122. See Calabresi \& Melamed, supra note 116

123. 382 B.R. 90 (Bankr. E.D. Mich. 2008).

124. Id. at $95-98$.

125. Id. at $102-03$.

126. Id. at $106-11$

127. See 11 U.S.C. §363(e) (2012).

128. Id. §362(d).

129. See 3 COLLIER ON BANKRUPTCY $9361.02[2]$ (16th ed. 2017).

130. See 11 U.S.C. § 361(1) (2012).

131. Id. §361(2).

132. See, e.g., In re Podzemny, No. 09-14226-j11, 2011 Bankr. LEXIS 567, at*29 (Bankr. D. N.M. 2011) (finding a $30 \%$ equity cushion sufficient, combined with cash collateral orders, to adequately protect creditor's interest in collateral); In re Campbell Sod, Inc., 378 B.R. 647, 654-55 
a Pareto test. It is an approximation, because adequate protection does not actually ensure that the property owner is no worse off. This is so for four reasons. First, the protection ordered by a court sometimes turns out to be inadequate, and the asset declines in value. ${ }^{133}$ Second, adequate protection does not compensate the owner for the time-value of money. ${ }^{134}$ Third, if the debtor intends to use the collateral, the court must value the collateral at its replacement value even if the judge thinks that the secured creditor would receive much less in a reorganization. ${ }^{135}$ Fourth, courts are split as to the timing of the valuation. Some courts value the collateral as of the time of filing while others value the collateral as of the time of the demand for adequate protection. ${ }^{136}$ Courts that take the latter approach only use a property rule once the property owner asks for it.

Bankruptcy uses adequate protection as a substitute for consent because the drafters of the Bankruptcy Code thought that the bargaining process would not always work perfectly. For example, if Plastech desparately needed the tools, Chrysler could threaten to seize them unless given a substantial accommodation. Adequate protection therefore shifts some of the bargaining power toward the debtor. Adequate protection is most often used in connection with secured credit. A security interest is a property right that allows the secured creditor to seize the collateral if the debtor does not complete the promised performance (often the repayment of a debt). ${ }^{137}$ However, inside of bankruptcy the debtor can continue to use the collateral after a default as long as it offers adequate protection. ${ }^{138}$ The debtor can grant a new creditor first priority in that collateral if it offers the old creditor adequate protection. ${ }^{139}$

The Bankruptcy Code imposes an additional Pareto test on the secured creditor at the end of the case. A debtor can approve a plan of

(Bankr. D. Kan. 2007) (finding a secured lender was adequately protected by an equity cushion where its collateral was likely to increase in value and debtor had a good prospect of reorganization); $c f$. Wilmington Tr. Co. v. AMR Corp. (In re AMR Corp.), 490 B.R. 470, 478 (S.D.N.Y. 2013) (noting the existence of an equity cushion "seems to be the preferred test in determining whether priming of a senior lien is appropriate under [11 U.S.C.] 364").

133. When this happens, the Bankruptcy Code provides the secured creditor with an administrative expense that has priority over all other administrative expenses except post-petition financing extended pursuant to $\S 364(c)(1)$. See 11 U.S.C. § 507(b) (2012).

134. See United Savs. Ass'n of Tex. v. Timbers of Inwood Forest Assocs. Ltd., 484 U.S. 365, 381-82 (1988).

135. See Assocs. Commercial Corp. v. Rash, 520 U.S. 953, 964 (1997) ("In sum, under § 506(a), the value of property retained because the debtor has exercised the ... 'cram down' option is the cost the debtor would incur to obtain a like asset for the same 'proposed TTT use."').

136. See 3 COLLIER ON BANKRUPTCY 361.02[2], [3] (16th ed. 2017).

137. See U.C.C. § 1-201(b)(35) (AM. L. INST. \& UNIF. LAW COMM'N 2003).

138. See 11 U.S.C. $\S \S 363,362$ (d) (2012).

139. Id. §364(d). 
reorganization that allows the debtor to keep the secured creditor's collateral without completing the promised performance as long as the debtor makes a new promise that the court believes has a value equivalent to the value of the security interest. ${ }^{140}$ Once again, this is not a purely Pareto test because of how the value of a secured claim is determined. ${ }^{141}$

This treatment of security interests reflects a belief that neither bargaining nor markets work perfectly in bankruptcy. If bargaining were costless, the debtor and the secured party would reach an agreement to pursue the efficient strategy regardless of the rule. If markets worked perfectly, the debtor could simply borrow more and repay the fullysecured creditor in full if the secured creditor refused to consent to an efficient use of the collateral. This raises the question whether it make sense to use the same Pareto standard to protect non-property interests. The next section describes a cost of using the Pareto test: it can lead to inefficient liquidation. This is not surprising. The Kaldor-Hicks test was developed precisely because the more demanding Pareto standard prevents some wealth-improving transactions. In Section D, we discuss some reasons why a Pareto standard nonetheless may still be attractive.

\section{Problems with the Pareto Standard}

Bankruptcy law could protect statutory priority entitlements with property rules by requiring the entitlement holder's consent for any deviation from priority. However, courts intuitively understand that, because bargaining is costly, this rule could destroy wealth. They adopt a Pareto standard on the grounds that if the disfavored creditors are at least as well off, they have no legitimate grounds for objection. ${ }^{142}$ However, there are several problems with imposing a Pareto standard. First, bankruptcy law is inconsistent and does not always impose such a standard. Second, while Pareto standards sometimes reduce the information that a court must acquire, in the reorganization context a Pareto standard will usually require more information than a Kaldor-Hicks standard. Finally, a Pareto standard can lead to inefficient liquidation.

\footnotetext{
140. Id. § 1129(b)(2).

141. See supra text accompanying notes $133-136$

142. Cf. In re Kmart Corp., 359 F.3d 866, 868 (7th Cir. 2004) (suggesting that critical vendor payment might be allowable under 363(b) if disfavored creditors are made better off as a result than if they were to receive a liquidation distribution); In re Crawford, 324 F.3d 539, 543 (7th Cir. 2003) (holding that the separate classification of claims resulting in disproportionate payment to different classes is permissible if the payment leaves disfavored creditors better off).
} 
In Jevic, the Supreme Court reversed a decision that paid lower priority general unsecured creditors instead of priority worker claims because the payments failed to pass a Pareto test; the workers were not better off. ${ }^{143}$ However, bankruptcy law frequently countenances decisions that benefit one creditor at the expense of another. Here, we briefly discuss two.

Consider the facts of Jevic. The funds to be distributed were from a settlement of a fraudulent conveyance lawsuit brought against a secured creditor. ${ }^{144}$ Because such suits tend to have a low probability of success and a high payout when they succeed, they create an inherent conflict between senior and junior claimants with regard to settlement. Consider a simple example. Assume Debtor, who is in bankruptcy, owes $\$ 100$ in priority claims, such as unpaid wages, and some arbitrarily large amount to general unsecured creditors. Debtor has no assets except for a fraudulent transfer action that it has brought against a secured creditor. This suit will succeed with probability $\mathrm{p}_{\mathrm{s}}$, and, if successful, recover $\$ 500$. Assume the secured creditor offers a settlement of $\$ 100$. Unless the estate is certain to prevail against the secured creditor, $p_{s}=1$, the priority claims are better off if the estate accepts the settlement because settlement repays the priority claimant in full. On the other hand, unless there is no chance that the estate would prevail, $p_{s}=0$, the general creditor is better off if the estate rejects the settlement and proceeds to trial because all of the proceeds of the settlement would go to the priority creditor. If the default rule is to go to trial, a Pareto test would prohibit the settlement. Alternatively, if the default rule is to settle, a Pareto test would require acceptance of the settlement. The law does not do this, and instead expects the debtor-in-possession to maximize the value of the estate, ${ }^{145}$ applying a Kaldor-Hicks rule and accepting the settlement if $\mathrm{p}_{\mathrm{s}}<0.2$.

These same numbers can be used to demonstrate that the choice between reorganization and liquidation also creates a conflict. Assume that the claims are the same but that the choice is between a liquidation that would yield $\$ 100$ and a reorganization that would yield $\$ 500$ with probability $\mathrm{p}_{\mathrm{s}}$. Here, the general unsecured creditors have nothing to gain from a liquidation because the entire $\$ 100$ would go to the priority

\footnotetext{
143. See Czyzewski v. Jevic Holding Corp., 137 S. Ct. 973, 986 (2017).

144. Id. at 980 .

145. 11 U.S.C. $\S 1107$ (a) (2012) (noting that a debtor in possession is charged with duties of trustee); La. World Exposition v. Fed. Ins. Co., 858 F.2d 233, 252-53 (5th Cir. 1988); LaSalle Nat'1 Bank v. Perelman, 82 F. Supp. 2d 279, 292-93 (D. Del. 2000); In re R.H. Macy \& Co., 170 B.R. 69 , 74-75 (Bankr. S.D.N.Y. 1994) (holding that a Chapter 11 debtor, acting as trustee, has a duty to act in best interest of the estate).
} 
claim. ${ }^{146}$ By contrast, the priority claim has nothing to gain from an attempted reorganization. The Code requires the full repayment of many priority creditors in a plan of reorganization, ${ }^{147}$ but a failed attempt at a reorganization can leave the firm unable to meet this burden and can lead to a liquidation that yields less than would have been yielded in an immediate liquidation.

Perhaps the reason why bankruptcy law does not apply a Pareto test to every decision is that a Pareto test requires some default rule or entitlement. Property rights provide clear entitlements, but in other cases the appropriate default rule is not always clear. Courts could remedy this deficiency. For example, they could decide that the default should be that all claims should be prosecuted to trial or that a firm's assets should be liquidated and require that those who wish to deviate from these positions satisfy a Pareto test. However, neither the Bankruptcy Code nor business considerations provide a good reason to adopt these as default rules rather than the rule that all claims should be settled and all firms should attempt a reorganization. By contrast, bankruptcy's priority rules do provide a fairly compelling default rule for distribution, a matter we return to below. ${ }^{148}$

Even if this inconsistency is a problem, it is not unique to bankruptcy. For example, if the government physically occupies private property, the Takings Clause of the United States Constitution protects the property with a liability rule. ${ }^{149}$ The property owner is entitled to compensation equal to the value (generally, the market value) of the property taken. ${ }^{150}$ However, if the government takes a substantial portion of the economic value of the property through regulation, the law applies a vague balancing test, and property owners rarely prevail in the reported cases. ${ }^{151}$ Consider also the law of trespass. Property owners can enjoin a threatened intentional trespass and sometimes can receive punitive damages if the trespass has occurred. ${ }^{152}$ However, if the law classifies the trespass as accidental, their property right is protected at most with a liability rule. ${ }^{153}$ 
We say "at most" because the law may impose a negligence standard that amounts to a Kaldor-Hicks test; the tortfeasor is only liable if the expected damages exceed the cost of precautions.

Requiring a Pareto improvement may also destroy wealth because some wealth maximizing reallocations will leave some parties worse off. The basic problem with a requirement of a Pareto improvement for a deviation from ordinary priority rules is the same problem present when using a Pareto test for public policy: it does not consider the size of the gains of the winners (here, the favored parties). Consider a simple example of a court considering a motion for a critical vendor order filed by Debtor. Debtor has $\$ 100,000$ in cash and no other assets. Debtor owes $\$ 50,000$ to the IRS, $\$ 50,000$ to Vendor and $\$ 450,000$ to Bank. All of the creditors are unsecured, but the IRS has priority under $\S 507(\mathrm{a})(8)$ of the Bankruptcy Code.

If Debtor is immediately liquidated, the IRS would receive the entire $\$ 50,000$ and be paid in full. All other creditors would get 10 cents on the dollar; Vendor would get $\$ 5,000$, and Bank would get $\$ 45,000$. Debtor can instead use $\$ 50,000$ of its $\$ 100,000$ in cash to buy more goods from Vendor and try to reorganize. If the reorganization succeeds, Debtor will have the remaining $\$ 50,000$ in cash plus assets worth $\$ 200,000$. If it fails, Debtor would just have the remaining $\$ 50,000$ in cash. The probability of success is $\mathrm{p}_{\mathrm{s}}$.

Vendor claims that it cannot or will not deliver the new goods unless Debtor pays its $\$ 50,000$ prepetition debt in full in addition to paying $\$ 50,000$ for the new goods ( $\$ 100,000$ in total). If Debtor cannot convince Vendor to deliver without paying and cannot find an alternative supplier, the payment would be a true critical vendor payment because the payment is necessary for any chance of a reorganization. The probability that payment is a true critical vendor payment is $\mathrm{p}_{\mathrm{CV}}$.

If we are trying to maximize aggregate wealth or seeking KaldorHicks efficiency, Debtor should elect reorganization as long as $p_{\mathrm{s}} \$ 200,000>\$ 50,000$, or the probability of success exceeds $25 \%$. The probability that the payment is a true critical vendor payment is irrelevant because its only effect is distributional. If the reorganization would have proceeded in the absence of the payment, then the amount the IRS and the Bank lost from the repayment of Vendor is precisely offset by Vendor's gain. To apply a Kaldor-Hicks test, the judge and the trustee or debtor-in-

damages unavailable when trespass involving cutting of timber is innocent); RESTATEMENT (SECOND) OF TORTS $\S 908 \mathrm{cmt}$. b (AM. LAW. INST. 1979) (stating that punitive damages are not awarded for "mere inadvertence, mistake, errors of judgment and the like"); $c f$. Harrod Concrete \& Stone Co. v. Crutcher, 458 S.W.3d 290, 294 (Ky. 2015) (noting that the damages measure for trespass depends on whether the trespass is innocent or willful). 
possession need only estimate the probability of success or the going concern value of the firm relative to its liquidation value. Even when they overestimate the probability of success, the loss in social wealth comes not from the repayment of the old debt but from the investment in the new project. The repayment of the old debt is just a question of distribution, which is irrelevant under the Kaldor-Hicks standard.

Now consider a rule that requires a Pareto improvement to justify a deviation. Tests for critical vendor orders that are based on the Pareto principle can be much more complicated to apply than rules based on the Kaldor-Hicks standard. But the application is not complicated in this stylized example because a Pareto improvement is only possible if success is certain. Note that because the IRS has priority, ${ }^{154}$ it is repaid in full in a liquidation. As a result, it is only ensured of being no worse off if there will certainly be enough assets to repay the IRS in full in an attempted reorganization. ${ }^{155}$ This is just an example of the conflict between senior and junior claimants. Because of the inherent option, the senior claimant is biased against continuation. There is a way to ensure that the IRS is no worse off. If the IRS's seniority was based on a security interest (if it had a property interest), it could demand "adequate protection" such as a security interest in other assets to protect it against the decline in the value of its collateral prior to the confirmation of a plan of reorganization. The Debtor could take a similar approach here, securing the IRS's consent by offering it a security interest. This means that a true Pareto test may import an adequate protection right for creditors with statutory priority, a right that they now lack. That is, a true Pareto test would grant priority claims a quasi-property right.

Ordinarily, junior claimants are biased towards continuation. But in this example the effect of the critical vendor order more than offsets this bias and biases Bank toward liquidation. Note that a successful reorganization following a critical vendor order would give Bank $\$ 150,000$, as the IRS must be paid out of the $\$ 200,000$ in total assets. If these debts are not paid in advance and there is still a reorganization, Bank would get $\$ 180,000$, as there would be $\$ 250,000$ in total assets and Bank would be entitled to $(\$ 450 / \$ 500)$ multiplied by the $\$ 200,000$ remaining after the IRS is repaid. If the reorganization fails, Bank would get nothing as the remaining $\$ 50,000$ would be used to pay the IRS. Therefore, Bank

\footnotetext{
154. See 11 U.S.C. $§ 507(a)(8)$ (2012).

155. The Bankruptcy Code would require the full repayment of the IRS in a plan of reorganization, 11 U.S.C. § 1129(a)(9) (2012), but the firm may lack the assets necessary to do so and thus may be forced to liquidate.
} 
is made no worse off by a critical vendor order if: $p_{S} \$ 150,000 \geq$ $\mathrm{p}_{\mathrm{CV}} \$ 45,000+\left(1-\mathrm{p}_{\mathrm{CV}}\right) \mathrm{p}_{\mathrm{S}} \$ 180,000$.

The first lesson the example teaches is that the Pareto standard requires the trustee (debtor-in-possession) and the court to do more work. Ordinarily one would think that Pareto tests are easier to apply than Kaldor-Hicks tests because when applying a Pareto test a court need only estimate the impact of the change on the disfavored party while a KaldorHicks test requires the court to estimate this loss relative to the gain of the favored party. This is similar to the debate over strict liability and negligence. A negligence rule requires a court to engage in a difficult costbenefit analysis as the court must weigh the cost of precautions against the expected cost of an accident. By contrast, strict liability only requires the court to estimate the plaintiff's loss, and the defendant may be in a better position to engage in the cost-benefit analysis because the defendant may have better information about the precautionary costs. ${ }^{156}$ Similarly, the Pareto rule of adequate protection may economize on information because the court need only estimate the risk of depreciation of an asset and need not consider the prospects of the firm's reorganization because the amount to which the secured claim is entitled is unrelated to the success of the reorganization.

However, this is not generally true for rules that protect unsecured claims. Although unsecured claims are never entitled to more than full payment, this usually is not a binding constraint; in bankruptcy, the unsecured claims are often residual claims. As a result, the court must estimate the prospects of the reorganization, here given by the probability of success, to estimate the amount that the unsecured claims would receive. This is the same information required in a Kaldor-Hicks test. However, to apply a Pareto test, the court must also determine whether reorganization would be possible without the critical vendor payment; they need to also estimate $\mathrm{p}_{\mathrm{Cv}}$. This difficulty becomes progressively worse if we added another demand for an early payment such as a demand for a roll-up.

Even if we assume that paying Vendor is necessary for any chance at a reorganization, $\mathrm{p}_{\mathrm{CV}}=1$, a rule requiring a Pareto improvement can still lead to inefficient liquidation. While a reorganization is socially optimal if $p_{s} \geq 0.25$, Bank is worse off if $p_{s}<0.30$. This bias toward liquidation may appear small, but remember that the critical vendor effect had to overcome

156. See, e.g., Robert Cooter \& Thomas Ulen, Law \& Economics 215 (6th ed. 2016). Occasionally a negligence rule will be less taxing. $I d$. at 223-24. For example, it may be obvious that the precautionary costs far exceed the defendant's loss, and the court can avoid the necessity of estimating damages by simply reassigning the entitlement by declaring that the action is not negligent. Id. 
the fact that the IRS's senior position biased Bank toward reorganization. The critical vendor bias becomes much stronger when there is a strong chance that the payment is not actually necessary for a reorganization. For example, if there is a $50 \%$ chance that the reorganization could proceed without the early repayment of vendor, $\mathrm{p}_{\mathrm{CV}}=0.5$, a critical vendor payment makes Bank worse off if the probability of success is less than $75 \%$, $\mathrm{p}_{\mathrm{s}}$ $<0.75$. Denying a critical vendor order does not guarantee liquidation; in this example there is still a $50 \%$ chance that the firm will reorganize anyway because the vendor was not critical. But it does mean that courts should deny critical vendor orders for firms with going concern value even though there is an even chance that this will mean liquidation.

Debtor, Vendor and Bank could avoid inefficient liquidation through bargaining. Vendor could demand less than full repayment of its prepetition claim in exchange for Bank's consent. However, if bargaining were costless, strong property rules that required consent for a deviation would suffice. Even without consent, Vendor could still satisfy a Pareto test by demanding less than a full $\$ 50,000$ payment or offer some offsetting payment so that the IRS and Bank are no worse off. There are at least two problems with this approach. First, Vendors often demand early payment because they say that they are liquidity constrained, and there is a chance that they are not bluffing. Second, a court would still need to determine $\mathrm{p}_{\mathrm{s}}$ and $\mathrm{p}_{\mathrm{CV}}$ to determine the payments required.

\section{In Defense of the Pareto Standard}

Bankruptcy law could dispense with a Pareto test and require that the disfavored parties actually consent to any deviation from ordinary priority rules. This is, in fact, what bankruptcy law does at the plan confirmation stage. Absent their consent, a court simply cannot confirm a plan of reorganization that fails to pay administrative expenses in full and in cash or that fails to pay unsecured creditors in full if equity holders receive any value under the plan. ${ }^{157}$ At that stage of the process, bankruptcy law requires the debtor to negotiate and obtain the consent of at least a supermajority of the claims in a disfavored class. ${ }^{158}$ A Pareto standard makes sense earlier in the process if time constraints make bargaining costly or impossible. Debtors often seek approval of critical vendor orders and rollups as part of their "first day orders," and they argue that delay could be fatal to a reorganization. Time is less obviously a factor in substantive

\footnotetext{
157. 11 U.S.C. § 1129(a)(9)(A), (b) (2012).

158. Id. $\S 1126$ (requiring, for class approval, two-thirds in amount and more than one-half in number of claims).
} 
consolidation. However, in many of these cases, the very argument for substantive consolidation is that a failure to follow corporate formalities makes it impossible to know which creditors have claims against which entity, and thus there are no clear entitlements from which to begin bargaining.

We defend the Pareto test against the Kaldor-Hicks alternative. Some commentators think that the law should adopt the latter. For example, David Skeel recently recommended that, where not prohibited by the Bankruptcy Code, courts should approve the trustee's decisions that maximize asset values of the estate and therefore maximize aggregate creditor recoveries. ${ }^{159}$ They should not worry about the equality of distribution as long as the deviations from equality are predictable and the trustee is not self-dealing.

We are doubtful. For one thing, there is an initial problem about the recommendation for bankruptcy law. If the trustee is charged with maximizing asset values, without regard to distribution, why not permit dispositions that increase the expected social welfare even if they reduce recoveries to creditors? For instance, assume that liquidation of the debtor's assets would give creditors more than they would receive in reorganization by an amount $X$. Why not allow the reorganization nonetheless if it produces community benefits that exceed the reduction in payoffs to creditors by at least $X$ ? If distribution to creditors is not a constraint on the disposition of estate assets, there is no reason a priori to take into account only the interests of creditors. ${ }^{160}$ There are two further doubts. First, higher courts may wish to use a Pareto test (or the even more extreme consent rule) to limit the power of bankruptcy courts either because of separation of powers concerns or because of concerns that informational constraints and agency costs will lead to biased decisionmaking. Second, the Kaldor-Hicks criterion ignores distributional considerations, and these may matter. It is morally important that losers actually be compensated for their loss, not just that the change is sufficiently beneficial that the winners could have compensated them and realized a profit. Some have suggested that giving debtors and courts more flexibility will lead to more equitable distributions, but the existing

159. See Skeel, supra note 1, at 703 ("[T]he real issues ... are policing self-dealing, reducing the risk of 'secret liens,' or maximizing the value of the debtor's assets."); $c f$. Richard A. Posner, Definition, Justification, and Comment on Conference Papers, 29 J. LEgAL STUD. 1153, 1154-55 (2000) (advocating the Kaldor-Hicks standard to guide common law decision making).

160. Below, we offer one possible reason and argue that this reason may also suggest that respecting the priority among creditors matters as well. See infra notes 183-184 and accompanying text. 
evidence does not clearly support this claim. Finally, ignoring the standard priority rules can have adverse effects on ex ante incentives.

\section{Limiting the Power of Bankruptcy Courts}

Suppose that A, who is rich and has a great need for B's property, takes it without B's consent. A argues that theft should not be illegal if he wants the item more than B and is willing and able to pay more than B is willing to pay to retain his own property. He would be right if courts used a Kaldor-Hicks test to determine whether a thief could take the property of another. However that is just not what our courts do, and even those who have advocated giving the bankrupt debtor more flexibility in deciding whom to pay do not explicitly argue that the debtor should be able to ignore property rights such as security interests.

The doctrines that we discuss do not threaten property rights as long as courts measure "adequate protection" correctly. For example, if a debtor wants to use cash collateral to make critical vendor payments, it must offer the secured creditor adequate protection. ${ }^{161}$ The doctrines do, however, threaten statutory priority rights. That is, critical vendor payments and roll-ups threaten the requirement that some unsecured creditors be paid before others and that when there is no reason to place one creditor above another they should share pro rata. Should these statutory priority rules be treated like property rights? We are inclined to say yes, but why? Part of the answer may lie in federalism and the separation of powers, and part may lie in the informational constraints faced by courts, particularly in the bankruptcy context. We consider these points separately.

\section{a. Federalism and the Separation of Powers}

Baird and Casey argue that superior courts construe ambiguous provisions of the Bankruptcy Code narrowly to limit the power of bankruptcy judges. ${ }^{162}$ Although Baird and Casey do not address critical vendor orders and roll-ups, these financing terms implicate the scope of that power. Courts could read $\S 363$ (b) of the Bankruptcy Code broadly to allow the courts to approve any use of the debtor's assets. However, this would raise separation of powers and federalism concerns. It would raise separation of powers concerns because Congress set forth priority

\footnotetext{
161. See 11 U.S.C. § 363(e) (2012).

162. See Douglas G. Baird \& Anthony J. Casey, Bankruptcy Step Zero, 2012 S. Ct. REV. 203, 205 (2013).
} 
rules. Some of these priority rules require pro rata distributions of similarly situated creditors in Chapter $7^{163}$ and an absence of unfair discrimination in Chapter 11. ${ }^{164}$ In addition, Jevic reminds us that deviations can also undermine the priority that Congress has granted to some creditors over those who would be favored by judicially sanctioned deviations. ${ }^{165}$ Separation of power considerations, Baird and Casey conclude, partly explain why bankruptcy courts understand that Code priorities limit their powers.

Baird and Casey's argument accurately describes the understanding superior courts have of their own powers. But it can justify that understanding too. The basic normative concern is that courts lack the authority to deviate from statutory priority rules, even when deviations increase net welfare. Federal judges, who are unelected, lack lawmaking power. Only Congress, not the courts, has the authority to permit welfareenhancing deviations. It is one thing for Congress to override property rights created by state and nonbankruptcy federal law, and authorize bankruptcy courts in prescribed circumstances to monetize them or diminish their value. It is quite another for courts to do the same without Congressional authorization, even when the priority override is welfareenhancing. This is a political objection to the judicial use of the KaldorHicks standard in bankruptcy.

\section{b. Information and Agency Problems}

The doctrines discussed above would raise less significant separation of powers concerns if Congress explicitly granted bankruptcy courts or the debtor the authority to determine distributional priorities. In a world of omniscient judges, a rule based on Kaldor-Hicks improvements would maximize the value of the estate. However, in a world of omniscient judges, there would be little need for rules of private property; judges could simply determine the best use of all assets. In reality, judges are not omniscient and must rely on the parties for their information. This problem can be especially acute in bankruptcy, as the judge may hear from only one side of the dispute or be supplied with limited information relevant to his decision. Other parties in interest may not be sufficiently organized or, if organized, unable to present relevant information to the court. In either case the court might have limited and possibly inaccurate information on which to base its decision.

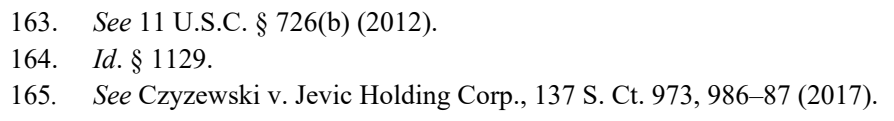


When protecting a property interest, a Pareto standard may impose a less severe informational demand on judges. For example, a rule that awards a tort victim or a contractual counter-party damages creates a form of Pareto standard. A court need only ensure that the tort victim is made no worse off by the tort or the counter-party is made no worse off by the breach. The tortfeasor and breaching parties can then decide their best course of action in light of the damages they must pay.

Bankruptcy may reduce the value of a secured claim to the value of the collateral, ${ }^{166}$ but once this is done, the secured claim is entitled to full repayment and is not entitled to any further payment. ${ }^{167}$ Therefore, courts need only ensure that the Debtor has taken sufficient steps to protect the secured creditor against a decline in the value of the property, and the court need not estimate the likelihood of a successful reorganization.

The same may not true of the priority rules because general claims and claims who enjoy statutory priority are likely entitled to some of the reorganization surplus. In the simple case where there is a priority creditor who would be paid in full in the event of a liquidation, the court could conduct a similar analysis, refusing to approve a deviation unless the full repayment of the priority creditor is adequately protected. However, in order to determine whether the disfavored creditors are at least as well off as they would be without the proposed deviation, a court must determine the expected value of their repayment. The court is not simply trying to ensure that the disfavored creditors are guaranteed to receive at least as much as they would have in a liquidation. As discussed above in Part B, this actually imposes a greater informational burden on the court: it must estimate both the firm's going concern value relative to its liquidation value and the probability that the firm could achieve this going concern value if the deviation did not occur.

Perhaps there is something more basic at work. Although Chapter 11 exists because markets are imperfect, courts are imperfect too. A rule that requires consent when a deviation is not a Pareto improvement merely requires negotiation in the tough cases. A bankruptcy court is unlikely to have reliable information about gains and losses early in the bankruptcy case when it might be called on to grant a critical vendor motion. Because they are made at the end of the case, the court may have better information about the consequences of other decisions such as whether to approve a plan of reorganization that includes substantive consolidation or that provides differential payments as between co-equal classes. However,

\footnotetext{
166. See 11 U.S.C. § 506(a)(1) (2012).

167. Note, however, the creditor is given an unsecured claim for the remainder of her original claim and may be entitled to some recovery on that claim.
} 
creditors arguably have better information at that point and are positioned to use it to bargain over the distribution of estate assets. A comparison between the court and the creditors with respect to the amount and quality of information about gains and losses does not favor the court.

Unlike the court, the bankrupt firm's managers may have very good information about the possible gains and losses from the various options. However, often they will not be impartial. Most reorganizing firms are small, ${ }^{168}$ and the managers and the equity holders are the same. This creates an obvious conflict of interest. Even in the largest bankruptcies, one can question how disinterested the managers really are. ${ }^{169}$ In the nonbankruptcy context, corporate law departs from the strong form of the business judgment rule in the mergers and acquisitions context because managers may be too reluctant to sell the firm if they would lose employment or too eager to sell if they receive a bonus from the acquirer or some other reward. ${ }^{170}$ Similarly, managers of bankrupt firms may be too reluctant to liquidate or sell the firm or too eager to sell the firm. In fact, the problem may actually be worse in bankruptcy. Outside bankruptcy the various stakeholders can use contract to mitigate these problems. However, inside bankruptcy, courts will ignore these contractual restrictions. ${ }^{171}$ Freed of the restrictions, managers can make asset allocation decisions to favor one set of claimants over others. They therefore cannot be counted on to make financing decisions that maximize asset value, rather than acting to benefit specific stakeholders at the expense of others. In these circumstances the debtor-in-possession's decisions are not entitled to a presumption of reasonableness. For this reason, the bankruptcy court cannot completely defer to the managers' decisions in determining whether their choices meet the Kaldor-Hicks test.

As a practical matter, courts may have to offer some deference to the managers' decisions because of the managers' better access to information. For example, bankruptcy courts will authorize the debtor-inpossession's decision to assume or reject executory contracts and

168. Note that excluding Chapter 11 cases with less than $\$ 1,000,000$ in assets reduced the sample size by more than half. See supra notes $92-93$, and the accompanying text.

169. Cf. Otte v. Mfgs. Hanover Commercial Corp. (In re Texlon Corp.), 596 F.2d 1092, 1098 (2d Cir. 1979) ("The debtor in possession is hardly neutral [with respect to the proposed crosscollateralization].")

170. See Unocal Corp. v. Mesa Petrol. Co., 493 A.2d 946, 954 (Del. 1985).

171. See, e.g., Steffan v. McMillan (In re Coordinated Fin. Planning Corp.), 65 B.R. 711, 714 (B.A.P. 9th Cir. 1986) (holding that a restrictive covenant, as an executory contract, can be rejected by trustee); In re Am. Trailer \& Storage, Inc., 419 B.R. 412, 441 (Bankr. W.D. Mo. 2009) (holding that modification of financial convenant permissible if modification does not inter alia "unduly harm" secured creditor's collateral position). 
unexpired leases or sell estate assets if made in good faith and on the basis of a reasonable business judgment. ${ }^{172}$ This is a deferential standard of review, comparable in content to the business judgment rule in corporate law. ${ }^{173}$

The business judgment rule gives the debtor-in-possession a lot of discretion. But this is true regardless of the standard the debtor-inpossession is to use to make financing decisions. This is because the judicial standard for reviewing these decisions is distinct from the duty bankruptcy law might impose on the debtor-in-possession in making the decisions. As a result, the business judgment rule is compatible with the debtor-in-possession making financing decisions based on a Kaldor-Hicks standard, a Pareto standard or any other standard. The standard of review therefore does not determine the standard governing the debtor-inpossession's choices.

A deferential standard such as the business judgment rule presumes that the debtor-in-possession's decisions accord with its duties. Reversal of its decisions requires substantial proof that the debtor-in-possession violated its obligations. The choice of standard governing the debtor-in-

172. See Sharon Steel Corp. v. Nat'l Fuel Gas Dist. Corp., 872 F.2d 36, 40 (3d Cir. 1989); Lubrizol Enters., Inc. v. Richmond Metal Finishers, Inc., 756 F.2d 1043, 1047 (4th Cir. 1985); In re Lionel, 722 F.2d 1063, 1071 (2d Cir. 1983) (authorizing the decision to sell the majority of estate assets).

173. See 3 Collier on BANKRuPtcy 9 365.02[2] (16th ed. 2017); Jesse Fried, Executory Contracts and Performance Decisions in Bankruptcy, 46 DuKE L. J. 517, 539 (1996); cf. In re Farmland Indus., Inc., 294 B.R. 855, 881 (Bankr. W.D. Mo. 2003). Executory contracts present yet another context in which many courts have rejected a Kaldor-Hicks test in favor of something that looks a little like a Pareto test. Some courts adopt a "balancing test" and refuse to allow a debtor to reject an executory contract if the damage to the counter-party would be disproportionately larger than the benefit to the estate. See Fried, supra, at 542-44. This balancing test is obviously based on a Kaldor-Hicks standard. However, most courts apply a "burdensome test" that allows a debtor to reject contracts if performance reduces the value of the estate. $I d$. at 540-42. If we ignore the possibility that the debtor could renegotiate with the counter-party after rejection, a burdensome test is quite similar to a Pareto test that asks whether the estate would be at least as well off through assumption, but it is not precisely the same. To see this, assume that the debtor has an executory contract with E. The debtor owes $\$ 50$ for goods already delivered under an executory contract and that the contract calls for the debtor to pay $\$ 150$ for new goods to be delivered under the contract and it would cost the counter-party $\$ 100$ to produce these goods. The debtor also owes $\$ 900$ to general creditors. A KaldorHicks test would instruct the debtor to assume the contract as long as the value of the goods to the debtor exceeds cost of performance, $\$ 100$. Note that the amount of the existing debt to the counterparty and the contract price are irrelevant under a Kaldor-Hicks test because their effects are purely distributional. A rule that instructs the manager to maximize the value of the estate would have the manager reject the contract as long as the value of the goods to the debtor was less than the sum of the outstanding debt and the price of the goods, $\$ 200$ because the debtor must pay $\$ 50$ to cure the default and then pay the $\$ 150$ purchase price to obtain the goods. By contrast, a Pareto test would have the manager reject the contract only if the value of the goods was less than $\$ 180$. The reason that the Pareto test would actually make the debtor more willing to assume contracts than the burdensome test is that some portion of the funds used to pay the counter-party for the goods would have flowed to the counter-party upon rejection to satisfy its claim. 
possession's decisions, therefore, matters if it is biased. For example, if the debtor-in-possession is too likely to assume executory contracts, a Pareto rule may be preferable, as it makes assumption more difficult. This is because a Pareto rule allows assumption of the contract only if its performance does not diminish the value of the claims of any creditor. Accordingly, a creditor can prevent assumption by demonstrating that assumption will diminish the value of its claim, even when assumption is a net benefit to the estate. Although a Pareto rule prevents assumption of these contracts, it also prevents a debtor-in-possession biased in favor of assumption to assume contracts that are not net beneficial contracts and assures that the contracts that are assumed are a net benefit to the estate. Consider an analogy. Assume that a legislature wants cars to travel at fifty-five miles per hour. Assume also that it knows that drivers routinely drive ten miles an hour above the speed limit because the police have difficulty proving guilt when the difference between the posted speed and the actual speed is less than ten miles an hour. Rather than simply posting a speed limit of fifty-five miles per hour and accepting traffic at sixty-five miles per hour, the town can post a speed limit of forty-five miles an hour and have its desired traffic speed of fifty-five. ${ }^{174}$

A Pareto test is not the exclusive means of adjusting for the effects of deference given to possibly biased managers. One can also adapt a Kaldor-Hicks test to demand that the debtor show that the gains from departing from the ordinary entitlements substantially outweigh the harms. This is, in fact, what courts do when they adopt a variant of a Kaldor-Hicks test. Consider, for example, the D.C. Circuit's announced test for substantive consolidation. Rather than adopt a pure Kaldor-Hicks test, the D.C. Circuit insists that "the demonstrated benefits of consolidation 'heavily' outweigh the harm." 175

Thus, the central question is whether the debtor-in-possession is likely to be biased in its financing decisions. As noted above, the debtor-inpossession tends not to be impartial in a significant number of reorganizations. It tends to make financing decisions that help itself or creditors with whom it has a relationship at the expense of other creditors. This bias argues for these decisions to be subject to a Pareto rule, even where the business judgment rule is the operative judicial standard of review.

174. Michael D. Gilbert, Insincere Rules, 101 VA. L. REV. 2185, 2185-86 (2015).

175. In re Auto-Train Corp., 810 F.2d 270, 276 (D.C. Cir. 1987). 


\section{Distributional Considerations Matter}

A rule based on Kaldor-Hicks improvements ignores distributional considerations. This is because the Kaldor-Hicks criterion does not require that the losers be compensated, and the failure to compensate affects distribution. Distribution in turn can matter. The point was not lost on either Kaldor or Hicks when they separately formulated what is now known as Kaldor-Hicks efficiency. In stating this standard of efficiency, both noted that actual compensation was a separate question. ${ }^{176}$ The observation acknowledges that the actual compensation of losers might be important for moral and other reasons. The Kaldor-Hicks standard, therefore, is at most only a necessary condition of social optimality. Distributional considerations can remain important for at least three reasons. First, fairness might require that the losers actually be compensated for their loss. Second, distribution may affect ex ante incentives. Third, distributional considerations matter because they create an incentive for rent-seeking.

David Skeel suggests that giving the debtor discretion whom to pay can benefit more vulnerable creditors. ${ }^{177}$ As an example, he cites the Detroit bankruptcy in which retirees recovered at a much higher rate than bondholders. ${ }^{178}$ However, even if one assumes that equity would give retirees more than bondholders, his example is not nearly as powerful as he assumes. All of the classes with bondholders consented to Detroit's plan of reorganization, ${ }^{179}$ and even the most ardent proponents of equality would allow deviations with consent. The real deviation from equality in Detroit's bankruptcy occurred with respect to classes comprised in part by involuntary creditors such as tort claimants, when Judge Rhodes overruled their unfair discrimination objection. ${ }^{180}$ It is far less clear that equitable (or efficiency) considerations demand that the retirees, represented by a union that bargained for their pensions and could have bargained for

176. See supra note 115

177. See Skeel, supra note 1, at 723 ("[Deviations] sometimes favor more vulnerable creditors, such as pension beneficiaries"); David A. Skeel Jr., Can Pensions be Restructured in (Detroit's) Municipal Bankruptcy? 1, 25 (Univ. Pa. Law Sch. Faculty Scholarship Paper No. 508, 2013), http://scholarship.law.upenn.edu/faculty_scholarship/508 (unfair discrimination may allow the precarious financial position of pensioners to justify a higher payout to them than to other general unsecured creditors).

178. See Skeel, supra note 1, at 734, 736.

179. In re City of Detroit, No. 13-53846, at *1, *16, *17 (Bankr. E.D. Mich. Nov. 7, 2014) (transcript of oral opinion), http://www.mieb.uscourts.gov/sites/default/files/notices/Oral Opinion_on_Detroit_Plan_Confirmation_Judge_Rhodes_FINAL_for_Release.pdf.

180. Id. at *28-32. 
increased amounts to be set aside to pay for the pensions, receive more than involuntary creditors.

The details of Skeel's example aside, giving the debtor discretion to discriminate in favor of particular creditors based on equitable considerations is troublesome. For one thing, the exercise requires a fairness standard that is elusive. Is it fair that retirees receive a greater distribution from the debtor's estate than tort creditors generally? Does fairness allow the greater distribution when a retiree has a certain level of wealth? With respect to the facts, what makes it fair that one class of claimants receive more than another class with claims of the same legal nature? Whether particular facts are relevant to the fairness of a distribution depends on the content of the standard of fairness. That standard is unlikely to support favorable treatment of an entire class of claimants, dependent as it might be on the circumstances of particular class members. ${ }^{181}$ A related point is that courts might lack the information required to apply a compelling standard of fairness.

An obvious problem in leaving the distribution of assets up to the debtor and the courts is that creditors will spend considerable resources trying to convince both that they are worthy of extra payment. The reallocation of the debtor's going concern value and litigation costs incurred to do so are unproductive. Allowing the debtor's Chapter 11 reorganization plan to equitably distribute assets by ignoring Code priorities encourages wasteful expenditures. ${ }^{182}$

Finally, the distribution of assets matters for ex ante incentives. Above we noted that Skeel calls for debtors and courts to maximize the value of the estate (the aggregate recovery of all creditors) rather than to maximize the social value of the firm. ${ }^{183}$ Not all bankruptcy scholars agree with this prescription. For example, Elizabeth Warren has argued that the debtor and bankruptcy courts should not confine themselves to the interests of creditors and shareholders, but should also consider the interests of other stakeholders such as workers and the broader community. ${ }^{184}$ If one is willing to abandon the exclusive concern with the entitlements of creditors, why not abandon entitlements altogether and consider the interests of creditors and other stakeholders equally? An

181. See Hynes \& Walt, supra note 35 , at 57-58.

182. See Roe \& Tung, supra note 79, at 1240.

183. See supra note 159 and accompanying text.

184. Elizabeth Warren, Bankruptcy Policy, 54 U. CHI. L. REv. 775, 777, 786 (1987). For a discussion of deviations from ordinary priority rules in the context of the debate between bankruptcy "traditionalists" and "proceduralists," see Vincent S.J. Buccola, The Janus Faces of Reorganization Law, 44 J. CORP. L. (forthcoming), https://papers.ssrn.com/sol3/papers.cfm?abstract_id=3041445. 
obvious answer is that such a rule would dissuade creditors from lending in the first instance.

The more a creditor will recover, the more credit it is willing to extend and the longer it will wait before trying to collect. Distribution rules in bankruptcy are implicit terms of the credit agreement between the debtor and its creditor. The judicial alteration of these rules encourages creditors to extend less credit or to impose credit terms more protective to it and possibly disadvantageous to the debtor. Although the alteration may permit value-maximizing uses of assets in bankruptcy in some cases, the dilution of these rules can produce inefficient ex ante incentives to supply the debtor with credit. The inevitable tradeoff between ex post and ex ante incentives does not systematically favor a judicial alteration of distribution rules. ${ }^{185}$

The point just made assumes that the debt agreement between the creditor and debt is socially optimal. In obtaining credit initially, the debtor will structure its loan agreement, taking into account its present financing needs against those it might have in the future. However, the parties may not take into account interests other than their own, and the agreement therefore sometimes may not be socially optimal. In these cases, Congress intervenes to enact socially optimal priority rules. For example, it might wish to put the IRS ahead of other creditors. The judicial alteration of bankruptcy's distributional rules undermines these policy choices.

\section{CONCLUSION}

Contrary to the familiar maxim, equity in bankruptcy is not equality. There are too many instances in which the law of bankruptcy reorganization, both statutory and decisional, enforces priorities among creditors and gives a preference to certain creditors over others. Equity is equality only in the purely formal sense that like claims are treated alike. Because equity in bankruptcy allows and sometimes requires inequality, the question arises as to the standards bankruptcy courts rely on in permitting unequal distributions. If equity in bankruptcy is not equality, when does it permit or require inequality in a Chapter 11 reorganization?

The Pareto standard reflected in a range of doctrines allowing deviations from equality has a defensible place in bankruptcy law. By

185. See Barry E. Adler \& George Triantis, Debt Priority and Options in Bankruptcy: A Policy Intervention, 91 AM. BANKR. L.J. 563, 564 (2017) (“As with any contract renegotiation, the objective is to improve efficiency ex post without disturbing the ex ante efficiency of the debtor's capital structure. The challenge is compounded when the ex post adjustment is done by judicial fiat instead of by consent, and the resulting complexity justifies judicial restraint in adjusting priorities."). 
assuring disfavored creditors a distribution at equal to what they would receive without the deviation, the standard eliminates their incentive to take inefficient precautions ex ante to avoid a lesser return in bankruptcy. The criterion also protects their legal entitlements or the monetary equivalent of them. True, allocations permitted by the Pareto criterion themselves may be morally objectionable, as the criterion allows unjustified inequality. ${ }^{186}$ Judged by a moral standard of fairness, deviation from the Bankruptcy Code's distribution rules in a way that violates the Pareto test might fairly favor a creditor or more closely approximate a fair distribution. But there is little reason to believe that the Code's distribution rules systematically violate or vindicate creditors' moral entitlements, or that bankruptcy courts deviating from these rules will track morally fair entitlements reliably. Although the Pareto criterion is not a plausible criterion of social optimality, it is a defensible one in bankruptcy reorganizations.

186. Cf. SEN, supra note 102, at 22 ("In short, a society or economy can be Pareto-optimal and still be perfectly disgusting."). 